Journal of Ancient Philosophy ISSN 1981-9471 - FFLCH/USP

www.revistas.usp.br/filosofiaantiga
J. anc. philos. (Engl. ed.), São Paulo, v.13, n.2. p. 65-95, 2019.

DOI: http://dx.doi.org/10.11606/issn.1981-9471.v13i2p65-95

\title{
A Vergonha Filosófica contra a Adulação Retórica no Górgias de Platão
}

\author{
Luiz Eduardo Freitas
}

In this article I intend to show how three different aspects of the Gorgias are interconnected: (1) The criticism towards Athenian rhetoric and pleasure versus the defense of a philosophical way of life, expressed through Socrates' theses and discussions with his interlocutors; (2) The dialogue's dramatic background and the refutations of Socrates' greedy interlocutors through shame; (3) Socrates' long discourses at the end of the dialogue, in which he admits the possibility of a good rhetoric and narrates how a punitive system would work in the afterlife. In order to do so, I first highlight Socrates' rebuttal of the relations between rhetoric and knowledge as well as pleasure and good through the inversion of common Athenian values (I). Secondly, I analyze how the dramatic devices of the dialogue function to show Socrates shaming his interlocutors (II and III). Finally, by analyzing the final myth and Socrates' final speeches (IV and V) I propose a new interpretation to the obscure suggestions of a good rhetoric in the final part of the dialogue: in the good rhetoric exhibited by Plato in the Gorgias, pleasure and adulation are substituted by the production of pain and shame.

\section{Introdução ${ }^{1}$}

O meu e o teu consentimento, portanto, serão realmente a completude da verdade (ó $\mu$ o

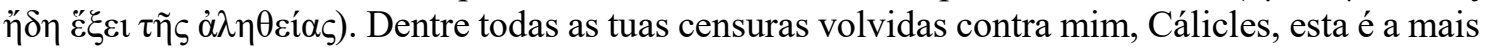
bela investigação: de que tipo deve ser o homem, com que deve ele se ocupar e até que ponto, seja ele velho ou jovem (487e6-488a2). ${ }^{2}$

\footnotetext{
${ }^{1}$ Este artigo é resultado de pesquisa de doutorado financiada pela FAPESP. Processo $\mathrm{n}^{\circ}$ 2017/18451-0, Fundação de Amparo à Pesquisa do Estado de São Paulo (FAPESP). Agradeço aos professores e aos colegas que leram versões prévias deste trabalho e ofereceram críticas e sugestões: Marco Zingano, Daniel Lopes, Marcos Tadeu Miranda, Antonio Kerstenetzky, Hugo Salustiano. Agradecimentos especiais a Fernando Muniz, que ao longo de anos inspirou e contribuiu para o desenvolvimento das ideias reunidas neste artigo, e a Roberto Bolzani, pelas críticas atenciosas e motivadoras.

${ }^{2}$ Utilizo a tradução de Daniel Lopes (2011) e o texto grego da edição de John Burnet (1968). As traduções livres para o português dos textos dos comentadores e intérpretes citados nas notas de rodapé são minhas.
} 
Journal of Ancient Philosophy ISSN 1981-9471 - FFLCH/USP www.revistas.usp.br/filosofiaantiga
J. anc. philos. (Engl. ed.), São Paulo, v.13, n.2. p. 65-95, 2019.

DOI: http://dx.doi.org/10.11606/issn.1981-9471.v13i2p65-95

Nos manuscritos medievais, o Górgias tem como subtítulo "Sobre a retórica". Apesar de ser a questão que introduz a discussão filosófica entre Sócrates e Górgias (449c-d), este não é o único tema do diálogo. Ao investigar a natureza da retórica, Sócrates pretende questionar os fundamentos que justificam a existência desta enquanto prática política. Ao questionar uma das instituições da democracia ateniense, Sócrates se aprofunda em questões que dizem respeito ao modo correto de se colocar na vida pública

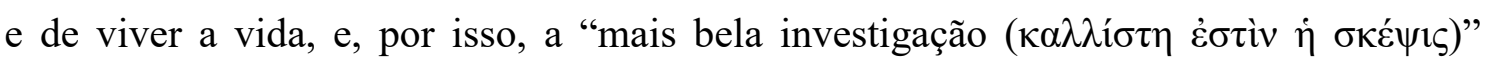
(487e7).

Poderíamos dividir o diálogo em quatro grandes partes: os três primeiros atos, em que Sócrates discute com três interlocutores que defendem a retórica, e uma parte final, em que as falas de Sócrates se tornam mais extensas e não há mais um respondente constante no diálogo. Enquanto a crítica socrática à retórica ocupa boa parte da discussão, a última seção do diálogo é mais propositiva; Sócrates disserta a respeito da possibilidade de uma boa retórica, ao que se segue uma narrativa sobre como se daria o julgamento das almas depois da morte.

O objetivo de Platão no Górgias é claro: comparar filosofia e retórica e, assim, estabelecê-las como práticas opostas. Ao seu interlocutor derradeiro, Sócrates afirma o que pretende: "depois de distingui-las e de concordarmos entre nós que se trata de duas formas de vida, investigar em que elas se diferem e qual delas deve ser vivida" (500d24). Com isso, o protagonista do diálogo e herói platônico pretende, é claro, clamar o lugar da filosofia enquanto a única prática com a qual “[o homem] deve se ocupar” (487e9), provando que apenas ela é capaz de possibilitar aos seus praticantes o conhecimento e, consequentemente, a vida justa e boa, tanto para o indivíduo quanto para a cidade. ${ }^{3}$

Para isso, ao longo do diálogo, Sócrates estabelece uma série de dicotomias relacionadas analogamente à oposição entre a retórica e a filosofia. A partir da inversão dessas dicotomias, ele opera também uma inversão das hierarquias entre os valores implicitamente estabelecidos entre elas. O caráter subversivo de seu objetivo no Górgias é reiterado na abertura do terceiro ato, quando Cálicles afirma que, caso as palavras de

\footnotetext{
${ }^{3}$ Nightingale (1995, p. 10, 11) afirma: "Para criar a filosofia como disciplina especializada, Platão precisava distinguir o que ele estava fazendo de todas as outras práticas discursivas que reivindicavam sabedoria. [...] É preciso enfatizar que os gestos de oposição e exclusão exercem papel fundamental nas muitas tentativas de Platão de marcar os limites da 'filosofia'. De fato, é precisamente ao designar certos modos de discurso e esferas de atividade como 'anti-filosóficas' que Platão pôde criar uma identidade separada para a 'filosofia'".
} 
Journal of Ancient Philosophy ISSN 1981-9471 - FFLCH/USP www.revistas.usp.br/filosofiaantiga
J. anc. philos. (Engl. ed.), São Paulo, v.13, n.2. p. 65-95, 2019.

DOI: http://dx.doi.org/10.11606/issn.1981-9471.v13i2p65-95

Sócrates fossem verdadeiras, "a vida de nós homens estaria de ponta-cabeça (ó ßíos

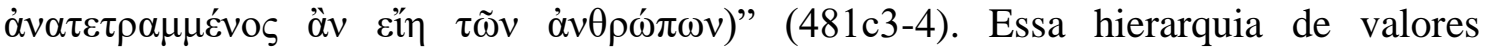
estabelecida no decorrer da discussão - segundo a qual o conhecimento é superior à opinião, sofrer injustiça é melhor que cometer injustiça, a saúde da alma é mais importante que a saúde do corpo, a $\tau \dot{\varepsilon} \chi v \eta$ é superior à $\varepsilon j \mu \pi \varepsilon \imath \rho^{\prime} \alpha$, o bem é superior ao prazer, e a condenação de um tribunal no pós-vida é mais justa do que a condenação de um tribunal ateniense - visa operar a inversão da hierarquia primeira, implicitamente proposta por seus adversários, entre retórica e filosofia.

Tanto o estabelecimento das dicotomias quanto a inversão dos valores subjacentes às duas práticas são conduzidos, evidentemente, por Sócrates. No entanto, poucas das teses que Sócrates avança no diálogo são aceitas com naturalidade por seus interlocutores, e a fortuna crítica do Górgias já atentou exaustivamente, nas últimas décadas, tanto para os problemas nos argumentos socráticos ${ }^{4}$ quanto ao fato de que existe um aspecto $\mathrm{ad}$ hominem nas refutações. ${ }^{5}$ Górgias, Polo e Cálicles, três dos personagens talvez mais confrontativos a Sócrates no corpus platônico, acabam sendo envergonhados e levados, através desta paixão ${ }^{6}$, a aceitar a derrota de suas posições. Essa aparente desconexão entre a universalidade dos temas e a contingencialidade do jogo de cena do diálogo causa controvérsias na interpretação do Górgias. Muitos comentários questionam a validade das conclusões desencadeadas pela vergonha que Sócrates provoca nos seus interlocutores. ${ }^{7}$ Afinal, quando se discute alguns dos temas éticos mais importantes, qual a legitimidade de ser refutado por vergonha de sustentar suas opiniões? Por que Platão precisa lançar mão deste artifício literário, apelando à psicologia de seus personagens, para justificar a razoabilidade dos argumentos propostos por seu protagonista?

Ao mesmo tempo, a parte final do diálogo, em que Sócrates dedica longas falas a narrar um mito e a defender sua posição como único verdadeiro político da cidade, parece

${ }^{4}$ Entre alguns estudos paradigmáticos, estão Irwin (1979), Cooper (1999), Vlastos (1995), Beversluis (2000).

${ }^{5}$ Principalmente Kahn (1983), McKim (1988), Moss (2005).

${ }^{6}$ V. 482c6-7, onde o próprio Cálicles refere-se à vergonha como $\pi \alpha ́$ os

${ }^{7}$ Por exemplo, Beversluis (2000, p. 342) parece concordar com Cálicles ao afirmar, sobre Sócrates, que "ainda que aparentemente seja um investigador honesto em busca da verdade, [Sócrates] é de fato um debatedor desonesto que vence por meio de truques dialéticos (482c4483a8)" (trad. livre). 
Journal of Ancient Philosophy ISSN 1981-9471 - FFLCH/USP www.revistas.usp.br/filosofiaantiga
J. anc. philos. (Engl. ed.), São Paulo, v.13, n.2. p. 65-95, 2019.

DOI: http://dx.doi.org/10.11606/issn.1981-9471.v13i2p65-95

formalmente desconectada da discussão travada anteriormente. O estilo do texto muda radicalmente: o filósofo, que para entrar na discussão exigiu dos demais participantes perguntas e respostas breves, para de adotar meias palavras e, em longos monólogos, faz críticas vorazes à retórica e aos seus participantes, além de afirmações audaciosas a respeito da filosofia e alusões à possibilidade de uma boa retórica, que seria bem diferente da que seus interlocutores defendem. Não só Sócrates prescinde de um interlocutor que faça as vezes de interrogado ou interrogador, como avança uma série de teses mais propositivas que parecem, à luz das discussões anteriores, obtusas, para além do alcance de seus interlocutores.

É possível separar, então, esses três aspectos bastante complexos do Górgias: a dimensão argumentativa, através da qual Sócrates, com perguntas e respostas, vai tentar provar a superioridade da filosofia à retórica; os elementos dramáticos, expressos no jogo de cena em que Sócrates enfrenta seus interlocutores e os envergonha diante de uma grande plateia; e o desfecho do diálogo, marcado por uma mudança de registro discursivo e por uma longa fala de Sócrates que abarca aspectos mitológicos e apologéticos.

Vou defender não apenas que esses três aspectos do diálogo estão conectados, mas também que a compreensão adequada de cada um depende do esclarecimento do que está implicado nos demais. ${ }^{8}$ A parte crítica do diálogo - composta pelos argumentos contra a retórica - só faz sentido dentro do registro discursivo específico do Górgias - a tentativa socrática de refutar seus interlocutores através da vergonha - por motivos que são sugeridos no trecho mais propositivo do texto - o final do diálogo, após a crise com o último interlocutor, em que Sócrates faz a defesa da filosofia e sugere a possibilidade de uma boa retórica. A nossa hipótese é de que Platão, no Górgias, ao mesmo tempo que justifica a sua crítica à retórica ateniense, estaria exibindo um exemplo do como uma boa

\footnotetext{
${ }^{8}$ Poder-se-ia objetar que a própria distinção desses três elementos já configura uma afronta à sua indissociabilidade no texto platônico. No entanto, dada a longa tradição de comentários a respeito do Górgias (e dos diálogos platônicos, de maneira mais geral), tal distinção já está posta pelo estabelecimento de diferentes vertentes de análises. Embora nos últimos anos haja uma crescente preocupação em se deter sobre os "elementos dramáticos" ou em fazer uma leitura "dialógica" do corpus platônico, não devemos perder de vista que a construção de argumentos constitui boa parte da composição textual dos Diálogos. Assim, uma leitura filosoficamente precisa deve conjugar os diferentes aspectos contemplados pelo texto, e talvez o melhor modo de o fazer contemporaneamente seja se servir dos diferentes métodos de interpretação estabelecidos na história dos estudos platônicos, nomeando os aspectos analisados de acordo.
} 
Journal of Ancient Philosophy ISSN 1981-9471 - FFLCH/USP www.revistas.usp.br/filosofiaantiga
J. anc. philos. (Engl. ed.), São Paulo, v.13, n.2. p. 65-95, 2019.

DOI: http://dx.doi.org/10.11606/issn.1981-9471.v13i2p65-95

retórica alternativa poderia funcionar, através da vergonha, para influenciar indivíduos pouco afeitos ao modo de vida filosófico.

Na próxima seção, retomarei os principais argumentos avançados por Sócrates no Górgias. Na seção II, explorarei o modo como ele constrange os seus interlocutores, através da vergonha, a aceitar suas teses ou a abandonar as convicções contrárias que eles inicialmente sustentavam - estratégia que encontra seus limites com o terceiro interlocutor do diálogo, na passagem que eu exploro na seção III. Na seção IV, apresentarei uma interpretação a respeito do mito e da última parte do diálogo. Por fim, na seção V, defendo a conexão entre esses diferentes aspectos do Górgias.

\section{As Inversões Socráticas}

Sócrates inicia a discussão com Górgias com uma abordagem já conhecida dos leitores de Platão: ele procura a natureza da retórica, e o que se segue será algo como uma busca definicional aos moldes dos primeiros diálogos.

$\mathrm{Na}$ interrogação de Górgias, Sócrates estabelece a primeira das hierarquias que serão estabelecidas ao longo da argumentação, entre crença ( $\pi$ í $\sigma \tau \iota \zeta)$ e conhecimento

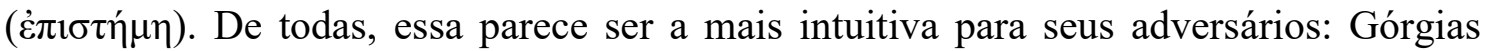
concorda prontamente com ela. O problema aparece quando o sofista aceita a definição proposta por Sócrates: a retórica é "o artífice da persuasão ( $\pi \varepsilon \imath \theta$ oṽ $\varsigma \delta \eta \mu 1 o v \rho \gamma o ́ \varsigma)$ que infunde crença, mas não ensina nada" a respeito "do justo e do injusto" (454e9-455a1). O avançar do argumento, aqui, não se dá a partir da inversão da hierarquia dos próprios critérios propostos - de conhecimento, de crença -, mas a partir da revelação de que a retórica, ao contrário da crença popular, não ensina a respeito de nenhum assunto ético, mas apenas convence sua audiência.

O alargamento da dicotomia epistemológica proposta ocorre através da analogia estabelecida por Sócrates na abertura do segundo ato do diálogo. Após obter de Polo a admissão de que o orador não necessariamente conhece "o justo, o belo, o bem”, Sócrates estabelece uma oposição mais profunda - poder-se-ia dizer, constitutiva - entre retórica e a verdadeira política a partir de uma analogia com atividades concernentes ao corpo:

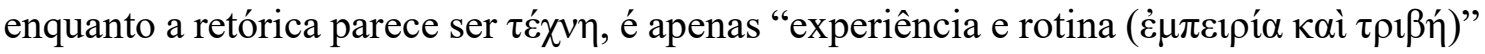


Journal of Ancient Philosophy ISSN 1981-9471 - FFLCH/USP www.revistas.usp.br/filosofiaantiga
J. anc. philos. (Engl. ed.), São Paulo, v.13, n.2. p. 65-95, 2019.

DOI: http://dx.doi.org/10.11606/issn.1981-9471.v13i2p65-95

(463b4). ${ }^{9}$ A retórica é, no que concerne aos assuntos da alma, apenas um simulacro

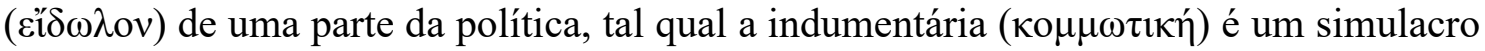
da ginástica $(\gamma v \mu v \alpha \sigma \tau ı \kappa \tilde{\eta})$ no que concerne aos assuntos do corpo.

Recurso que ocupa papel central no segundo ato do Górgias, a analogia é fundamental para Sócrates dar o passo que irá consolidar a desqualificação da retórica. Para ilustrar por que a retórica não pode ser qualificada como discurso de conhecimento - sendo relegada ao registro epistêmico inferior da crença - e a sua potência enquanto

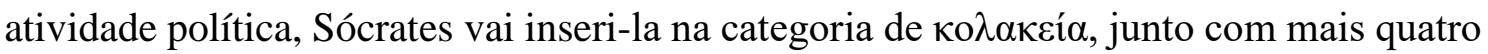
práticas. A culinária (ỏ

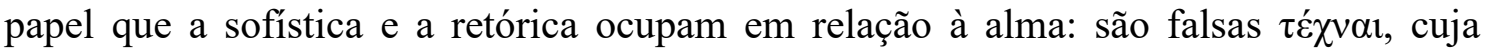
potência de engano se dá através da produção de prazer. ${ }^{10} \mathrm{~A}$ culinária representa uma falsa medicina na medida em que parece estar fazendo bem para o corpo, mas está apenas produzindo prazer. Também a cosmética ocupa papel de prática falsa: produz no espectador apenas a ilusão da beleza, que só poderia ser atingida em seu estado real através da ginástica e do exercício do corpo. ${ }^{11}$

O objetivo último da analogia é submeter todo o grupo de falsas $\tau \dot{\varepsilon} \chi v \alpha \iota$ a uma desvalorização. A potência da retórica é justamente essa produção de prazer no espectador que a culinária ou a cosmética operam: através da adulação, cria a ilusão de que aquele que está exercendo tal prática conhece verdadeiramente os seus assuntos (concernentes à justiça, no caso da retórica, concernentes à saúde do corpo, no caso da culinária...). ${ }^{12} \mathrm{O}$ uso da analogia se justifica através da semelhança de simulação, que liga as falsas $\tau \varepsilon ́ \chi v \alpha \iota$

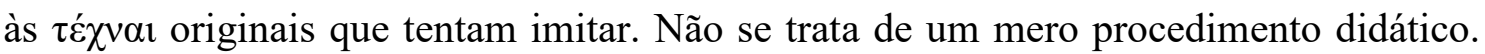

\footnotetext{
${ }^{9}$ De acordo com Nussbaum (2009, p. 84), no imaginário grego já havia uma relação implícita

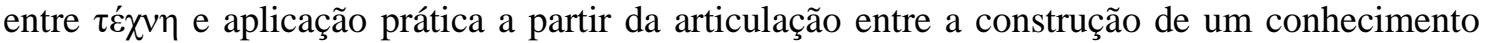
sistemático a respeito de deliberações morais e a eliminação da contingência.

${ }^{10}$ Nas palavras de Muniz (2011), existe uma relação intrínseca entre o rebaixamento dessas

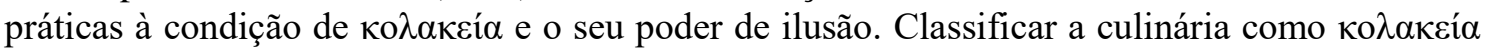
significaria "não poder dar conta racionalmente da finalidade a que se propõe". Então é "exatamente dessa 'irracionalidade' que provém a sua força ilusória, pois sua capacidade de produzir a identificação imediata entre o prazer e o bem se deve à evidência prática construída a partir dos sabores gustativos" (p. 141).

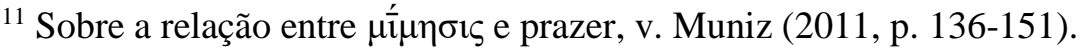

${ }^{12}$ Para funcionar, a analogia, fundamentada na potência do engano do prazer, tem como condição uma plateia de pessoas cujas almas não sejam capazes de discernir a prática verdadeira da enganosa, como "em meio a crianças ou a homens igualmente ignorantes como crianças" (464d57).
} 
Journal of Ancient Philosophy ISSN 1981-9471 - FFLCH/USP www.revistas.usp.br/filosofiaantiga
J. anc. philos. (Engl. ed.), São Paulo, v.13, n.2. p. 65-95, 2019.

DOI: http://dx.doi.org/10.11606/issn.1981-9471.v13i2p65-95

Está em jogo uma relação entre imagens já conhecidas e familiares para estabelecer equivalência com uma relação semelhante entre duas práticas relativamente novas - entre as quais, por sua vez, o Sócrates de Platão deseja estabelecer hierarquia similar. Platão está tentando tornar evidente, assim, a vantagem para a alma do real conhecimento da justiça (subentendidamente, alcançada apenas através da filosofia) sobre a prática da retórica, em um mesmo nível de clareza que, por suposto, se estabelece uma superioridade da medicina em relação à culinária, ou da ginástica em relação à indumentária quanto ao bem do corpo humano. Assim, através da analogia que será recuperada ao fim do diálogo, Sócrates estabelece uma relação entre prazer, ilusão e crença. ${ }^{13}$

A denúncia evoca a dimensão imoral, vergonhosa, que Sócrates parece atribuir à retórica na discussão com Polo - e que é explicitada através do estabelecimento derradeiro da hierarquia dicotômica, transposta em seguida para uma distinção estética, entre belo e vergonhoso. A tese socrática à qual Platão dedica a maior parte deste segundo ato - é mais vergonhoso ( $\alpha i \sigma \chi \rho o ̀ v)$ cometer injustiça do que sofrê-la, e isto é algo aceito por todos - sedimenta o ataque à retórica ao mostrar que, sem nenhuma espécie de critério moral ou conhecimento, fundamentada somente em prazeres, e estimulando a desordem na alma e na cidade, ela é não só a prática mais vergonhosa, como também a pior (464e-465a).

Os ṕń fazem; muito pelo contrário, estimulam a vida voltada aos prazeres e fundamentam-se no seu cultivo. ${ }^{14}$ Conforme as insinuações - que, ao longo do diálogo, ficam cada vez mais explícitas - de que os praticantes da retórica visam, através da prática enganosa, apenas o enriquecimento próprio para o usufruto fútil das vantagens obtidas pelo poder político, o prazer é determinante não só no modo como a retórica realiza a sua potência de adulação para imitar uma prática política, como também é o fim último almejado daqueles que a dominam. Por isso, para realizar a crítica à retórica, é determinante a teoria ética

\footnotetext{
${ }^{13}$ Uma segunda hierarquia sugerida por Sócrates, entre alma e corpo - por ser a alma que comanda o corpo, é possível distinguir entre as verdadeiras e as falsas $\tau \dot{\varepsilon} \chi v \alpha \iota$-, fundamentada na capacidade do prazer de enganar o corpo, adianta a crítica ao hedonismo do terceiro ato do diálogo: "Ademais, se a alma não comandasse o corpo, mas ele tivesse autocomando, e se a culinária e a medicina não fossem por ela perscrutadas e discernidas, mas o próprio corpo as discernisse tendo como medida o deleite que lhe advém, seria de grande valor o dito de Anaxágoras, meu caro Polo - tens experiência no assunto: todas as coisas reunidas se diluiriam em uma única coisa, visto que seria indiscernível o que é relativo à medicina, à saúde ou à culinária." (465c7-d6)
}

${ }^{14}$ Sócrates, nesse aspecto, iguala os retóricos aos sofistas (519c3-d4). 
Journal of Ancient Philosophy ISSN 1981-9471 - FFLCH/USP www.revistas.usp.br/filosofiaantiga
J. anc. philos. (Engl. ed.), São Paulo, v.13, n.2. p. 65-95, 2019.

DOI: http://dx.doi.org/10.11606/issn.1981-9471.v13i2p65-95

estabelecida por Sócrates no diálogo, que desqualifica a satisfação dos prazeres corporais, relacionando estes às partes inferiores das hierarquias estabelecidas entre alma e corpo, e afirmando que eles causam uma distorção na alma. ${ }^{15}$.

O terceiro ato do diálogo é dedicado principalmente à discussão sobre o prazer. É preciso revelar a potência corruptiva deste para derrotar a última grande objeção teórica de seus interlocutores. Sócrates ilustra o caráter sempre provisório da satisfação dos apetites através de algumas imagens, entre as quais a do jarro furado, que precisa sempre ser preenchido novamente - metáfora para a parte da alma onde estão os apetites dos ignorantes, cuja demanda por preenchimento serve para suprir uma dor que provém da falta constante, tal qual a falta proveniente da fome ou da sede. Essa deficiência intrínseca ao apetite, relacionada às aparências e ao engano, faz com que a satisfação dos prazeres seja um processo constante, de forma que a sua plenitude nunca é alcançada. Uma vez que os apetites nunca podem ser plenamente satisfeitos, é preciso constantemente recorrer aos prazeres. Se alguém tem a parte apetitiva da alma estimulada desse modo, ou seja, se alguém tem o prazer como o fim último a ser almejado, volta-se a uma vida de vícios e intemperança.

A relação da retórica com o prazer e com a aparência autoriza o desdobramento da dicotomia inicial, entre retórica e filosofia, em diferentes níveis: epistemológico, entre crença e conhecimento; ontológico, entre simulacro e original; moral, entre injusto e justo; estético, entre vergonhoso e belo, e sensorial, entre prazer e dor. As primeiras oposições, embora contestadas pelos interlocutores de Sócrates, são facilmente aceitas; mas, para fazer avançar os critérios estéticos e sensoriais, o filósofo precisa lançar mão de alguns artifícios argumentativos ardilosos. Tendo estabelecido as principais teses e argumentos críticos do diálogo, gostaria de retomar o modo como ocorrem as disputas entre os personagens do Górgias, e o modo como as teses socráticas são impostas aos interlocutores.

\footnotetext{
${ }^{15}$ Para justificar uma espécie de ordem da alma, no Górgias, Sócrates vai apelar para a ideia segundo a qual "a virtude de cada coisa, seja do artefato, do corpo, da alma, ou de qualquer outro vivente, não advém da maneira mais bela aleatoriamente, mas pelo arranjo, pela correção e pela

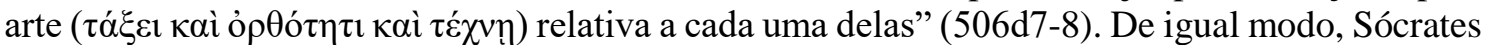

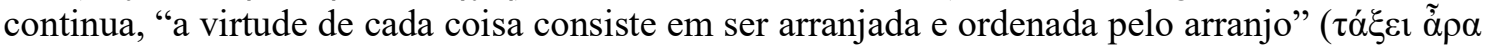

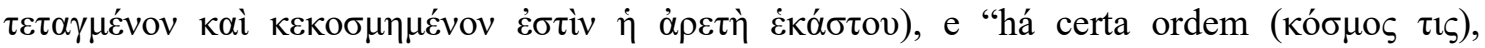
apropriada a cada coisa, que torna boa cada uma delas". Disso decorreria que "a alma dotada da ordem que lhe é própria é melhor do que a desordenada" (506e).
} 
Journal of Ancient Philosophy ISSN 1981-9471 - FFLCH/USP www.revistas.usp.br/filosofiaantiga
J. anc. philos. (Engl. ed.), São Paulo, v.13, n.2. p. 65-95, 2019.

DOI: http://dx.doi.org/10.11606/issn.1981-9471.v13i2p65-95

\section{As Refutações e a Vergonha}

Proponho, a seguir, uma breve análise dos procedimentos adotados nas refutações dos interlocutores de Sócrates no Górgias de Platão. Em todas as três refutações que Sócrates tenta efetuar no diálogo, a vergonha ocupa papel proeminente, seja evitando que um interlocutor fale o que realmente pensa (como é o caso de Górgias), ou mesmo provocando a negação de certas asserções inicialmente bastante convictas (como acontece com Cálicles). Sócrates também faz uso recorrente do vocabulário relacionado à vergonha ( $\alpha i \sigma \chi v ́ v \eta)$, principalmente na parte final, na discussão com Cálicles, como se a paixão pudesse ser um empecilho à conclusão da discussão filosófica. Ao mesmo tempo que a vergonha nunca é explicitamente analisada nas discussões - ao menos não nos moldes das discussões definicionais de Socrátes -, o método de refutação neste diálogo é, por si só, bastante significativo.

Ainda mais se considerarmos os interlocutores que Platão coloca em cena. A divisão do diálogo, em três grandes discussões, dá lugar à participação de três personagens com traços de personalidade bem característicos. Górgias, representação ficcional da figura histórica que conhecemos, consagrada figura pública estrangeira em Atenas e professor de retórica há muitos anos, tem como ponto fraco a sua reputação pública. Polo, também uma possível figura histórica, com um tratado a respeito da retórica mencionado en passant (462b), pertence a uma geração mais jovem e sente-se mais à vontade para questionar os pressupostos socráticos. Já Cálicles, o último interlocutor do diálogo, é o personagem mais agressivo e radical que Sócrates enfrenta ao longo dos Diálogos; deixando explícita sua animosidade contra a filosofia, com duras críticas ao método e à moral socráticos, faz uma defesa aberta da tirania e do hedonismo. Cada um, à sua maneira, representa diferentes aspectos da retórica combatidos por Sócrates.

Como vimos anteriormente, a discussão entre Sócrates e Górgias cumpre a função de esclarecer a relação entre retórica e conhecimento. Górgias se mostra surpreendentemente competente em atender às exigências da dialética socrática. Depois de ter concedido que a retórica não é conhecimento sobre o justo e o injusto, o orador afirma que seus alunos necessariamente devem aprendê-los; assim, ainda que a retórica não seja constitutivamente identificada ao conhecimento, haveria um comprometimento 
Journal of Ancient Philosophy ISSN 1981-9471 - FFLCH/USP www.revistas.usp.br/filosofiaantiga
J. anc. philos. (Engl. ed.), São Paulo, v.13, n.2. p. 65-95, 2019.

DOI: http://dx.doi.org/10.11606/issn.1981-9471.v13i2p65-95

moral por parte dos professores de retórica. O problema para Sócrates é que, ao mesmo tempo, Górgias se exime de responder pelos atos injustos que seus alunos possam vir a cometer. A incoerência fundamental que Platão denuncia na discussão com Górgias neste primeiro ato do diálogo - isto é, entre as duas premissas concedidas pelo professor de retórica, que afirma, ao mesmo tempo, (a) ensinar sobre o que é o justo e o injusto, e (b) não se responsabilizar pelos atos injustos de seus alunos - serve para deslegitimar a retórica enquanto $\tau \varepsilon ́ \chi v \eta{ }^{16}$

O ponto fundamental aqui é que Sócrates só teria obtido de seu interlocutor a concessão de (a) porque este estaria envergonhado de dizer o que realmente pensa. A denúncia é feita por Polo quando interrompe a discussão, dando início ao segundo ato do diálogo:

Porventura julgas - só porque Górgias ficou envergonhado (ฤฺ $\chi \chi v v \theta \eta)$ de discordar de ti em que o rétor conhece o justo, o belo, o bem, e que se alguém o procurasse sem conhecê-los, ele próprio o ensinaria, decorrendo em seguida, talvez advinda desse consentimento, alguma contradição no argumento (coisa que muito te apraz ( $\alpha \gamma \alpha \pi \alpha \underline{\alpha} \varsigma$ ), pois é tu a lhe formular perguntas do gênero) pois, julgas que alguém negaria conhecer o justo e poder ensiná-lo aos outros? Mas conduzir a discussão para esse lado é muito tosco (461b4-c4)

Górgias não teria sido ingênuo de não perceber o caminho traçado por Sócrates, muito mais explícito que na refutação dos dois antagonistas seguintes. Mais do que isso: poderia ter impedido a refutação caso admitisse que a retórica não tem compromisso com o ensino da justiça - o que, segundo o próprio Polo, seria a admissão que verdadeiramente

${ }^{16}$ A refutação de Górgias é objeto do escrutínio de muitos comentadores. São reconhecidos principalmente dois problemas no argumento socrático. Em primeiro lugar, há uma concepção de conhecimento implicada na premissa segundo a qual o conhecimento do justo implica necessariamente somente a prática de ações justas (de modo que quem conhece o que é justo jamais praticaria ações injustas - outra premissa estabelecida no argumento). Essa concepção está presente na posição intelectualista socrática nos primeiros diálogos, mas não é necessariamente difundida no imaginário popular grego, de modo que é possível questionar a adesão tão rápida de Górgias a esse passo do argumento. Cf. Irwin (1993, p. 126); Cooper (1999, p. 45). Em segundo lugar, a própria base a partir da qual o argumento é construído - a saber, a diferença entre crença e conhecimento - parece incompatível com as ideias difundidas pelo Górgias histórico, e passam incontestadas pelo Górgias ficcional representado por Platão. V. McComiskey (2002), que afirma: "os textos existentes revelam que a epistemologia de Górgias é relativista". Em seus escritos sobre

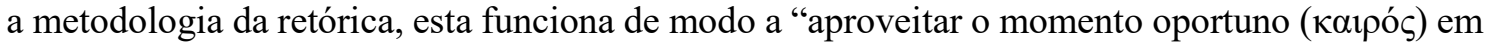
que certos tipos de linguagem podem ser utilizados para unir a consciência subjetiva em um desejo comunitário por ação". Por isso, "Kaıpós não pode funcionar como a base de uma epistemologia fundacionalista, uma vez que qualquer hora é o 'momento certo' quando alguém possui a verdade" (idem). 
Journal of Ancient Philosophy ISSN 1981-9471 - FFLCH/USP www.revistas.usp.br/filosofiaantiga
J. anc. philos. (Engl. ed.), São Paulo, v.13, n.2. p. 65-95, 2019.

DOI: http://dx.doi.org/10.11606/issn.1981-9471.v13i2p65-95

refletiria sua opinião. ${ }^{17}$ Mas, como respeitada figura pública, estrangeiro em Atenas ${ }^{18}$ ambas características que, além de serem factuais se considerarmos a figura histórica na qual o personagem é baseado, são informações enfatizadas no próprio texto ${ }^{19}$ - jamais poderia admitir isso em uma situação pública, tal qual a que serve de pano de fundo para o diálogo. ${ }^{20}$

A vergonha é colocada em pauta sub-repticiamente por Sócrates no segundo ato do diálogo, quando uma das premissas propostas pelo filósofo e admitidas por Polo será a de que é mais vergonhoso cometer injustiça do que sofrê-la - fundamental para provar a tese socrática que fechará esta parte da discussão, de que cometer injustiça é também pior do que sofrê-la.

Neste segundo embate, Sócrates quer provar que a defesa da vida do tirano aquele que, segundo a visão de Polo, tem a melhor vida, pois é capaz de cometer injustiças impunemente e, assim, satisfazer seus desejos - é vergonhosa. As opiniões de Polo, baseadas no senso comum ${ }^{21}$, são facilmente dispensadas por Sócrates, e a posição de recuo do orador ao final do segundo ato pode ser mais adequadamente atribuída a uma perplexidade embaraçada do que uma compreensão completa das objeções socráticas. $O$ movimento, segundo posterior diagnóstico feito por Cálicles ${ }^{22}$, é semelhante ao da discussão com Górgias: Sócrates leva Polo a sentir vergonha de sustentar a sua opinião inicial, sendo obrigado a "fechar o bico" (482e2).

\footnotetext{
${ }^{17}$ Note-se que, no Mênon, o personagem homônimo também deixa claro que Górgias não afirma ensinar sobre a virtude (95b8-c5).

${ }^{18}$ Conforme afirma Charles Kahn: "Depois de Sócrates tê-lo encorajado a enfatizar o poder que beira a onipotência oferecido por seu treinamento para aqueles que desejam 'governar outros homens em sua própria cidade' (452d7), como poderia Górgias admitir abertamente que dá poder a homens que são moralmente incompetentes ou pior? Se houvesse algo que serviria como boa desculpa para levar Górgias para fora da cidade rapidamente (...), seria tomar o caminho de Polo e anunciar que oferece treinamento a homens que não sabem nem se importam com o que é certo e errado, o que é bom e o que é mau para a cidade" (1983, p. 80).

${ }^{19}$ V. 487a7-8, por exemplo.

${ }^{20}$ Conforme nota Dodds (1990, p. 188), a presença da audiência é mencionada explicitamente em 455c5-d1, 458b4-c2, 473e4-5 e 490b1-2. A respeito da plateia, Beversluis (2000, p. 291, n. 3) a define como "Uma plateia de ouvintes anônimos que periodicamente clamam pela continuação da discussão e cuja presença, discreta mas ubíqua, confere uma concretude palpável para as

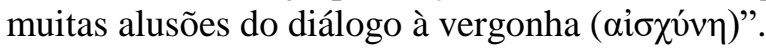

${ }^{21}$ V. 471e3, por exemplo.

$22482 \mathrm{c} 2$
} 
Journal of Ancient Philosophy ISSN 1981-9471 - FFLCH/USP www.revistas.usp.br/filosofiaantiga
J. anc. philos. (Engl. ed.), São Paulo, v.13, n.2. p. 65-95, 2019.

DOI: http://dx.doi.org/10.11606/issn.1981-9471.v13i2p65-95

A principal premissa concedida para o argumento funcionar e Sócrates conseguir refutar Polo é a de que é mais vergonhoso cometer injustiça do que sofrer injustiça. $\mathrm{O}$

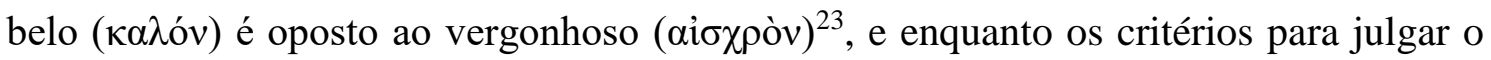
primeiro são benefício e prazer, os critérios para julgar o segundo são dor e mal. ${ }^{24}$ Como cometer injustiça não supera sofrer injustiça em dor, cometer injustiça só pode ser pior do que sofrer injustiça. ${ }^{25}$

${ }^{23}$ Oposição já feita anteriormente por Sócrates em 459b.

${ }^{24}$ A estrutura da argumentação completa é a seguinte:

(P1) É pior (кókıov) sofrer injustiça do que cometer (a tese de Polo, a ser refutada. A refutação não só vai negar 1, mas estabelecer o inverso: cometer injustiça é pior para o agente).

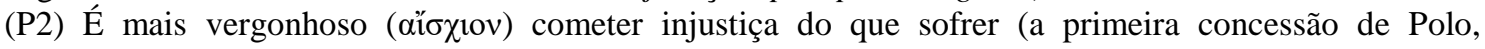
homologoumenon, da qual a refutação é derivada);

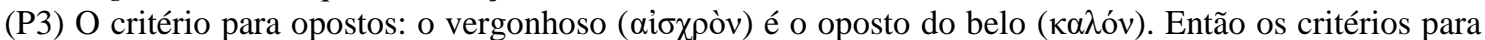
julgar uma coisa vergonhosa vão ser os opostos dos critérios para julgar algo belo (assumido em 475a4b2);

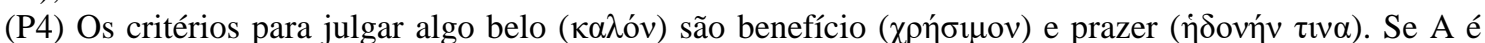
admirável, é por benefício, prazer ou ambos (a segunda concessão de Polo, o resultado de uma sequência de exemplos em 474d2-475a4);

(P5) Os critérios para julgar algo vergonhoso são os opostos de prazer e benefício (ou bem), a saber, dor e mal (a partir de 3 e 4 );

(P6) Se A é mais admirável que B, A excede B em prazer ou utilidade ou ambos (a partir de 4);

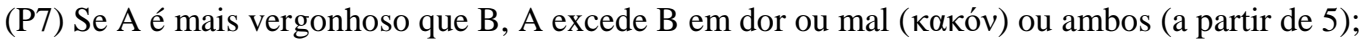

(P8) Uma vez que cometer injustiça é mais vergonhoso do que sofrer injustiça (a partir de 2), a primeira precisa exceder a segunda em dor, mal ou ambos (a partir de 7);

(P9) Cometer injustiça não excede sofrer injustiça em dor (a terceira concessão de Polo, dada em 475c14);

(P10) Portanto cometer injustiça não excede sofrer injustiça em dor (de 9);

(P11) Portanto cometer injustiça excede sofrer injustiça em mal, ou seja, cometer injustiça é pior (a partir de 8-10).

${ }^{25}$ A natureza um tanto oblíqua do argumento já foi objeto de objeções de muitos comentadores. Nota-se o problema que poderíamos chamar de "supressão de perspectiva": Sócrates, ao usar os conceitos em relação a diferentes agentes e objetos, compara casos que seriam incomensuráveis por não terem o mesmo ponto de referência da ação. Há duas ocorrências desse problema no argumento. Mais notavelmente abordada em um célebre artigo de Gregory Vlastos, a primeira ocorrência se dá através da uma mudança entre as concessões que Sócrates obtém de Polo entre (4) e (9) (ver supra): enquanto na primeira refere-se ao prazer em relação à perspectiva dos

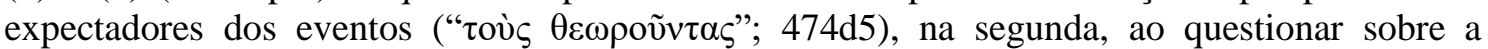
quantidade de dor de quem sofre ou comete injustiça, parâmetro constituído em oposição ao prazer (475a2), julga-se a partir da perspectiva dos participantes da ação. Segundo Vlastos (1995, p. 63), "a pergunta que Sócrates deveria ter feito seria 'qual é mais doloroso para aqueles que observam ou contemplam os dois eventos?'. Para essa pergunta, a resposta é, no melhor dos casos, indeterminada". O segundo problema é ainda mais grave, na medida em que impacta a validade da conclusão final - de que cometer injustiça excede sofrer injustiça em mal. Como nota Dodds (1990, p. 249), "quando Polo disse que cometer injustiça era menos admirável, ele claramente

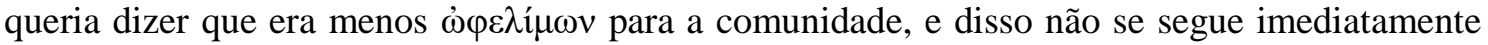
que é menos $\grave{\varphi} \varphi \lambda i_{\mu} \omega \omega \mathrm{v}$ para o agente". Ou seja, mesmo se ignorássemos a supressão de perspectiva das premissas anteriores, como faz, por exemplo, Charles Kahn, "a conclusão em 11 permanece uma inferência válida das premissas, mas apenas se cometer injustiça é pior do que sofrer injustiça for lido com a elipse aberta: pior para um ou outro, por exemplo, pior para a 
Journal of Ancient Philosophy ISSN 1981-9471 - FFLCH/USP www.revistas.usp.br/filosofiaantiga
J. anc. philos. (Engl. ed.), São Paulo, v.13, n.2. p. 65-95, 2019.

DOI: http://dx.doi.org/10.11606/issn.1981-9471.v13i2p65-95

É bastante curioso que Polo não questione a noção socrática de vergonha, abruptamente insurgente na conversa, já que a própria participação do personagem na discussão se dá a partir de uma crítica à postura envergonhada de Górgias. Que Polo admita uma inserção da vergonha como critério de valoração na discussão pode ser atribuído às suas raízes retóricas, que exigem uma proximidade com concepções morais do senso comum, ou mesmo à sua inexperiência na dialética. ${ }^{26}$

De qualquer modo, a inserção da vergonha neste momento do diálogo acontece em dois níveis: ela é determinante não só para o desenvolvimento conceitual da discussão, por estar presente no que poderíamos chamar de nível argumentativo do texto, mas também para a construção dramática - ou seja, ela é parte do argumento de Sócrates como critério moral determinante, mas é também uma emoção que afeta Polo psicologicamente, e aparece como motivo de sua refutação e afastamento da conversa. A conexão aqui explícita entre esses dois níveis é crucial para o leitor, porque indica um uso consciente da vergonha como elemento dramático por parte do autor dos Diálogos.

A derrota de Polo dá lugar à entrada de Cálicles, último interlocutor do diálogo. Cálicles irá retomar o motivo da derrota dos interlocutores anteriores: tanto Górgias quanto Polo foram refutados porque ficaram com vergonha de manter suas verdadeiras posições. ${ }^{27}$ Cálicles é algo como um interlocutor ideal - Sócrates afirma ironicamente porque exibe a franqueza necessária para falar o que pensa (486e-487a).

A questão do prazer ocupa papel fundamental no terceiro ato do diálogo. Ela é apresentada como o cerne das teses calicleanas, fundamentadas na valorização do hedonismo para a defesa de uma vida de sucesso político. Para provar que a retórica não é uma prática que vale a pena ser perseguida, e que o melhor modo de viver é voltar-se para o verdadeiro conhecimento exercido pela filosofia, Sócrates precisa, então, refutar o hedonismo de Cálicles.

Após Cálicles afirmar que a vida feliz é aquela em que se permite satisfazer os próprios apetites ( $\left.\dot{\pi} \Uparrow \theta v \mu \mu_{\alpha} \alpha\right)$, obtendo o máximo de prazer após eles se dilatarem ao máximo (491e-492a), a argumentação se desdobra através de uma série de imagens. A

sociedade como um todo" (Kahn, op. cit., p. 91). Mas "não há nada nas premissas forte o suficiente para justificar" (idem) a conclusão específica no final do argumento, de que cometer injustiça é pior para $\mathrm{o}$ agente.

${ }^{26}$ V. $448 \mathrm{~d} 1 \mathrm{ss}$

$27482 \mathrm{c}-\mathrm{e}$. 
Journal of Ancient Philosophy ISSN 1981-9471 - FFLCH/USP www.revistas.usp.br/filosofiaantiga
J. anc. philos. (Engl. ed.), São Paulo, v.13, n.2. p. 65-95, 2019.

DOI: http://dx.doi.org/10.11606/issn.1981-9471.v13i2p65-95

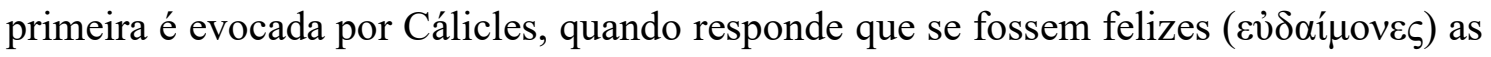
vidas dos homens que não têm mais carência pela saciedade de apetites, "seriam felizes ao máximo as pedras e os cadáveres" (492e5). Sócrates rebate com uma imagem supostamente provinda "de um contador de mitos da Sicília ou da Itália”, a do jarro furado que serve de metáfora para a parte da alma onde estão os apetites dos ignorantes, que precisam sempre ser preenchidos novamente para suprir uma dor que provém da falta constante - tal qual a falta proveniente da fome ou da sede (493b-d). Cálicles se mostra pouco abalado com este exemplo, ao qual responde novamente com a imagem da pedra. Sócrates afirma, em contrapartida, que seu oponente está defendendo não a vida de pedras ou cadáveres, mas a de uma tarambola, um pássaro que, enquanto come, defeca. ${ }^{28}$

Depois de fazer uma ressalva - "tu, porém, não te atordoes nem te envergonhes

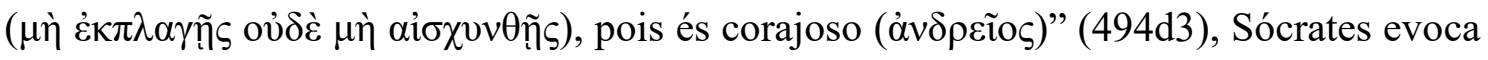
duas imagens decisivas: a vida de alguém com "sarna e coceira", que viveria permanentemente se coçando e tendo prazer ao se coçar; e o exemplo "culminante" desta

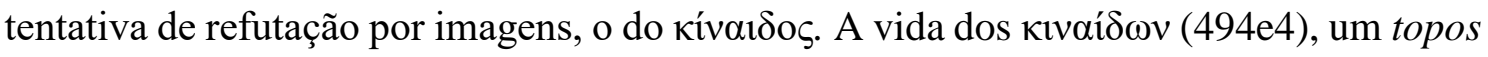
repudiado socialmente em uma Atenas baseada em valores majoritariamente masculinos, é a imagem vergonhosa por excelência. É difícil achar um correspondente exato para a tradução, mas a imagem evoca a figura de um homem adulto que pratica sexo anal em posição passiva - por prazer sexual e/ou em troca de dinheiro. Por isso é visto como afeminado e, dado todo o contexto do androcentrismo grego e das etiquetas estabelecidas para relações homossexuais, está em uma posição social bem pouco respeitada. ${ }^{29}$ Tratase, portanto, da metáfora última para a vida de um hedonismo indiscriminado, o que faz Cálicles recuar. A intenção de Sócrates é clara: pretende que Cálicles, ao se deparar com exemplos estapafúrdios, desista de suas teses, assim como fizeram os interlocutores anteriores. No entanto, ao contrário desses, Cálicles não parece se dar por vencido.

\footnotetext{
28 "Um pássaro de hábitos sujos e identidade incerta" (Dodds, 1990, p. 306).

${ }^{29}$ V. Freitas (2018), onde levanto a hipótese de que a imagem é evocada numa relação de intertextualidade com a Antíope de Eurípides, mencionada em algumas passagens da discussão.
} 
Journal of Ancient Philosophy ISSN 1981-9471 - FFLCH/USP www.revistas.usp.br/filosofiaantiga
J. anc. philos. (Engl. ed.), São Paulo, v.13, n.2. p. 65-95, 2019.

DOI: http://dx.doi.org/10.11606/issn.1981-9471.v13i2p65-95

\section{Os Limites da Vergonha}

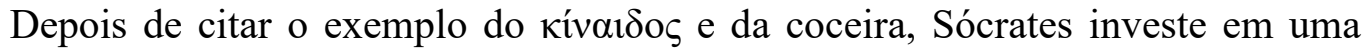
refutação formal da identidade entre bem e prazer. ${ }^{30}$ Em 497 c, Sócrates está prestes a demonstrar que o par prazer-dor não pode ser identificado ao par bom-mau porque, enquanto os dois elementos do primeiro par podem acontecer ao mesmo tempo em uma mesma pessoa (beber/realizar um prazer - enquanto se tem sede/dor), o segundo não pode. Independentemente da legitimidade do $\operatorname{argumento}^{31}$, Sócrates se aproxima do que geralmente o levaria à conclusão de uma refutação: demonstrar a incoerência entre as premissas com as quais seu interlocutor está concordando. ${ }^{32}$

Ainda que possamos admitir a hipótese de que há uma vergonha implícita no comportamento de Cálicles, o personagem, a partir deste ponto da discussão, reiteradamente sabota as tentativas socráticas de $\varepsilon \grave{\varepsilon} \varepsilon \gamma \chi 0 \varsigma$ através da desvalorização da própria dialética socrática e da filosofia.

Mesmo antes da conclusão da refutação formal, Cálicles parece estar se enfadando da conversa. 497a8: "Não entendo os teus sofismas, Sócrates"; 497b8: "Mas Sócrates é sempre assim, Górgias, pergunta coisas pequenas, desprovidas de valor, e as refuta”. Após ameaçar deixar a discussão com Sócrates, ele só se mantém em cena após

${ }^{30}$ As objeções seguintes de Sócrates já foram investigadas e analisadas exaustivamente. V. Santas (1979), Irwin (op.cit.), Guthrie (op.cit.), Kahn (op.cit.)

${ }^{31}$ Irwin (1979, pp. 201-4), por exemplo, a questiona.

${ }^{32}$ As duas objeções ao hedonismo subsequentes ao processo de refutação por imagem, que tentam basicamente provar que a identificação entre bem e prazer é falsa, podem ser resumidas pela seguinte estrutura (Kahn, op. cit., p. 107):

Objeção $1(495 e-497 d)$ :

1. O bem e seu oposto não podem acontecer simultaneamente no mesmo lugar; do mesmo modo, não cessam juntos;

2. O prazer e seu oposto (dor) encontram-se simultaneamente, e param juntos (por exemplo, o prazer de beber dura somente enquanto há a dor da sede);

3. Portanto, o prazer não é o bem.

Objeção 2 (479e-499b):

1. Homens inteligentes e corajosos são melhores do que homens estultos e covardes (tese moral de Cálicles);

2. O prazer é bom, e a dor é má (tese hedonista de Cálicles);

3. As pessoas são boas pela presença de boas coisas, más pela presença de coisas más (aceito em 497e1-3);

4. Pessoas com mais bens são melhores do que aquelas com menos (a partir de 3);

5. Pessoas com mais prazer são melhores do que aquelas com menos (a partir de 2 e 4);

6. Mas estultos podem ter tanto prazer quanto homens inteligentes; covardes podem ter tanto prazer quanto (ou mesmo mais) que homens corajosos;

7. Estultos são tão bons quanto homens inteligentes; covardes são tão bons quanto (em alguns casos, melhores) do que homens corajosos (a partir de 5 e 6). (contradiz 1) 
Journal of Ancient Philosophy ISSN 1981-9471 - FFLCH/USP www.revistas.usp.br/filosofiaantiga
J. anc. philos. (Engl. ed.), São Paulo, v.13, n.2. p. 65-95, 2019.

DOI: http://dx.doi.org/10.11606/issn.1981-9471.v13i2p65-95

intervenção de Górgias ${ }^{33}$, com um rompante de irritação. ${ }^{34}$ É então que Cálicles admite não estar mais sequer levando a discussão a sério.

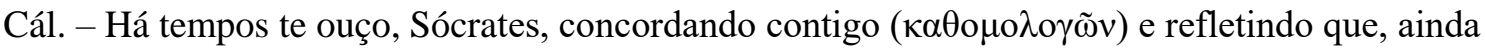
que alguém te conceda algum ponto por brincadeira, te apegas a isso contente como um garoto. Pois tu julgas, de fato, que eu ou qualquer outro homem não consideramos que há prazeres

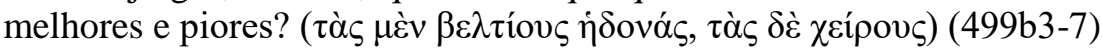

Não é preciso ir muito longe para ver como a admissão de uma distinção entre “prazeres melhores e piores” legitima, em um nível formal, as objeções de Sócrates. ${ }^{35}$ É bastante usual ler nesta passagem a refutação do hedonismo de Cálicles, uma vez que ela contradiz a identidade anteriormente defendida entre prazer e bem. Mas, enquanto do ponto de vista argumentativo, o artifício faz avançar a crítica de Sócrates ao hedonismo, do ponto de vista dramático, ele não se mostra eficiente. O desdém de Cálicles pela conversa e seu reiterado repúdio à filosofia ganham destaque no texto. Cálicles parece não reagir ao modo esperado por Sócrates e mantém-se irredutível. Além disso, continua apresentando objeções violentas contra a discussão, e manifesta diversas vezes sua vontade de parar de ser interrogado por Sócrates. ${ }^{36}$ Mais importante, ele mesmo não parece se perturbar por mudar de opinião, e exprime sua irritação diante do "apego infantil" de Sócrates a pontos que se conceda a ele "por brincadeira" ( $\pi \alpha i \zeta \omega v)$ (499b5). A expressão, não por acaso, nos remete ao vocabulário utilizado pelo personagem ao caracterizar a filosofia e o modo de vida de Sócrates: uma atividade que só é aceitável para quando se é jovem. ${ }^{37}$

No final do diálogo, tamanha é a relutância de Cálicles em continuar a conversa que obriga Sócrates a adotar algumas estratégias pouco usuais para poder concluir seu

\footnotetext{
33 "Isto não é tua competência, Cálicles. Submeta-te à refutação ( $\dot{\varepsilon} \xi \varepsilon \lambda \varepsilon ́ \gamma \xi \alpha$ ) como Sócrates quiser!" (497b8; também posteriormente, em 501c8)

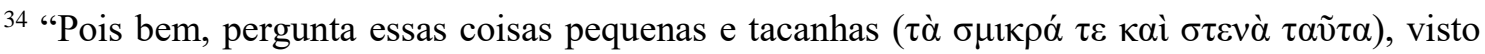
que é do parecer de Górgias!"

${ }^{35}$ Cooper (1999, pp. 72-73) discorda de que essa afirmação seja incompatível com a primeira versão do hedonismo formulada por Cálicles, que não exigiria a satisfação de todos os apetites.

36 495b7, 497a6, 497b6-7, 499b4-8, 501c7, 504c4, 505c, 506c4, 507a4, 510a1, 511a4, 513c4, $514 \mathrm{a} 4,515 \mathrm{~b} 5,515 \mathrm{e}, 516 \mathrm{~b} 4,516 \mathrm{c} 8,516 \mathrm{e} 8,519 \mathrm{~d} 8,522 \mathrm{e} 9 \ldots$

37 Também chama atenção o modo como Cálicles se refere à filosofia como algo "ridículo

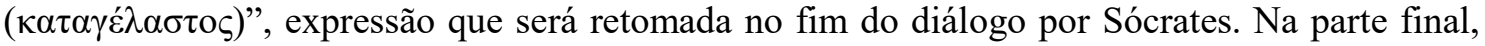
muitas das acusações de Cálicles encontrarão ecos e respostas nas palavras de Sócrates, particularmente no seu monólogo final. V. Levy (2014).
} 
Journal of Ancient Philosophy ISSN 1981-9471 - FFLCH/USP www.revistas.usp.br/filosofiaantiga
J. anc. philos. (Engl. ed.), São Paulo, v.13, n.2. p. 65-95, 2019.

DOI: http://dx.doi.org/10.11606/issn.1981-9471.v13i2p65-95

argumento, como inventar uma discussão imaginária em que o próprio Sócrates responde por Cálicles ${ }^{38}$ e fazer longos monólogos. ${ }^{39}$ A té o fim do diálogo, Cálicles não dá o menor sinal de estar convencido por Sócrates, ainda que seja constrangido por Górgias a continuar na discussão.

Os limites persuasivos da filosofia já tinham sido postos explicitamente em tema quando Cálicles, através de uma previsão sombria, alude à probabilidade de que Sócrates, caso julgado em um tribunal, fosse incapaz de persuadir sua audiência e sujeito à condenação de morte (486a-b). Como já foi observado em inúmeras leituras do diálogo, esta alusão ao julgamento de Sócrates relaciona diretamente o Górgias à Apologia. ${ }^{40}$ Como veremos a seguir, Sócrates postula, através do mito final do diálogo, o seu verdadeiro julgamento para o pós-vida; o julgamento de uma plateia fictícia de pessoas que pensem como Cálicles certamente não daria veredito diferente do de sua condenação histórica.

Somente através de um impasse dramático radical deste tipo Platão poderia realmente mostrar a animosidade de Cálicles em relação a Sócrates, ou as limitações da dialética de lidar com alguém que é, de saída, avesso à temperança ( $\sigma \omega \varphi \rho \sigma$ vó $)$ ) exigida pela racionalidade filosófica. ${ }^{41}$ A filosofia e a defesa de um modo de vida pautado pela temperança - em que os valores relacionados à virtude e ao bem são internamente coerentes, por terem passado pelo crivo do exame dialético - revelam-se, até mesmo em um registro discursivo, radicalmente incompatíveis com o modo de vida tirânico, que tem como prioridade a realização dos prazeres e apetites "naturais" de um homem superior

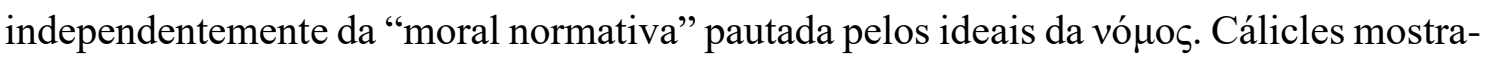
se irredutível tanto no nível do conteúdo de seu discurso, uma vez que não admite as

\footnotetext{
${ }^{38} 506 \mathrm{c}-507 \mathrm{a}$
}

${ }^{39} 519 \mathrm{~d} 7$ - "Sóc - E tu me constrangeste a agir como um verdadeiro orador público, Cálicles, porque não desejaste responder."

${ }^{40}$ Guthrie (1978, p. 295): "o principal objetivo do Górgias pode ser visto como uma nova defesa de Sócrates. Há de fato muitos ecos da Apologia [...]". Sobre a importância do tema do vaticínio no diálogo, v. Lopes (op. cit., pp. 99-116).

${ }^{41}$ Muniz (2011, p. 167): "Pois o que demonstra a conversa entre os dois é menos a oportunidade da concordância que o impasse radical - se isso é verdadeiro, o Górgias revela-se, nesse sentido, o mais aporético dentre os diálogos socráticos: aporia dos discursos e modos de vida inconciliáveis. [...] não há dialética nesse encontro, mas sim uma divergência radical que não pode ser reduzida ou resolvida." 
Journal of Ancient Philosophy ISSN 1981-9471 - FFLCH/USP www.revistas.usp.br/filosofiaantiga
J. anc. philos. (Engl. ed.), São Paulo, v.13, n.2. p. 65-95, 2019.

DOI: http://dx.doi.org/10.11606/issn.1981-9471.v13i2p65-95

refutações formais, quanto no nível dramático, à medida que não se deixa dominar pela vergonha de afirmar sua posição violenta.

A insuficiência da argumentação socrática para convencer seu interlocutor, se não se revela explicitamente no nível estritamente argumentativo, uma vez que o filósofo oferece a seus leitores uma possível refutação formal do hedonismo calicleano, é ressaltada no nível narrativo, já que Cálicles sai da discussão sem ter suas crenças abaladas pelo método dialógico. Afinal, é plausível considerar a possibilidade de um filósofo encontrar um interlocutor tão convicto de seus valores que seja em larga escala intocável pela argumentação racional. Não deveria ser surpresa que este comportamento possa advir, se de ninguém mais, de alguém que defende o modo de vida do tirano. Mas qual o objetivo da presença de um personagem tão arredio em um momento tão crucial da argumentação filosófica de Platão? Se Platão queria que interpretássemos o terceiro ato do Górgias como uma vitória de Sócrates, por que não obtemos em qualquer momento uma admissão de derrota por parte de Cálicles? É preciso buscar compreender por que Platão escolhe compor assim o fim de seu diálogo.

\section{A Boa Retórica}

A refutação dos três defensores da retórica abre caminho para a última parte do Górgias. Como alternativa ao modo de vida relacionado à retórica e ao cultivo dos prazeres, está a vida voltada para a filosofia. Como vimos, o objetivo de delimitar os campos de atuação das práticas e de seus praticantes está previsto na estratégia argumentativa de Sócrates desde o começo. Ele planeja, ao adentrar a discussão à "devida maneira de participar da guerra e da batalha" (447a1-2) ${ }^{42}$, expor as insuficiências das definições de retórica expressas por Górgias para revelar uma dimensão da prática da qual seus praticantes - por mais experientes que sejam, como o estrangeiro de Leontinos - não estão conscientes, ou cujas implicações não são capazes de admitir publicamente: que ela não visa nenhuma produção de conhecimento, de justiça ou de bem, mas apenas a produção de certo prazer em seus espectadores. Desmascarada a falsidade da prática e identificada sua relação com o prazer, a atividade é exposta, e seus defensores, questionados.

${ }^{42}$ V. Muniz (2011, p. 108). 
Journal of Ancient Philosophy ISSN 1981-9471 - FFLCH/USP www.revistas.usp.br/filosofiaantiga
J. anc. philos. (Engl. ed.), São Paulo, v.13, n.2. p. 65-95, 2019.

DOI: http://dx.doi.org/10.11606/issn.1981-9471.v13i2p65-95

A despeito da relutância de Cálicles em continuar participando da discussão, ou talvez justamente porque responde mecânica e desinteressadamente às perguntas, Sócrates vai estabelecer uma série de características que distinguem a retórica praticada em Atenas tanto da prática filosófica, quanto de uma possível boa retórica e da verdadeira $\tau \varepsilon ́ \chi v \eta$ política. O objetivo, de acordo com Sócrates, é descobrir qual o melhor modo de vida a ser vivida: "se é a [vida que Cálicles exorta a Sócrates], fazendo coisas apropriadas a um homem fazer, tais como falar em meio ao povo, exercitar a retórica, agir politicamente como hoje vós agis, ou se é a vida volvida à filosofia" (500c3-7).

A partir da oposição entre o grupo de práticas que se voltam apenas ao prazer, sem preocupação com quais são melhores e piores, e as que visam o bem na alma de um ou múltiplos espectadores (501d1), uma série de outras práticas serão inseridas na

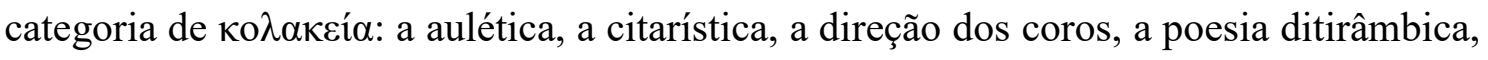
e, finalmente, a poesia - que, despida de canto, ritmo e metro, seria apenas “certa oratória pública" identificada à retórica (502c9-10).

A possibilidade de uma boa retórica - à qual Sócrates alude quando propõe investigar o nome de alguém que não tenha praticado o tipo de "lisonja" - é contemplada pela oposição de "uma parte [da retórica]", que "seria lisonja e oratória pública vergonhosa", ao passo que "a outra seria bela", a que "se dispõe para tornar melhores ao máximo as almas dos cidadãos e as defende dizendo o que é melhor, seja isso mais ou menos aprazível aos ouvintes" (503a5-9).

Entre os critérios para que a retórica seja verdadeira, é preciso que ela conceda

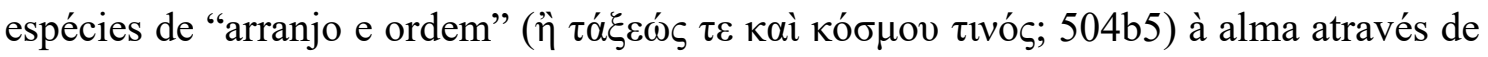

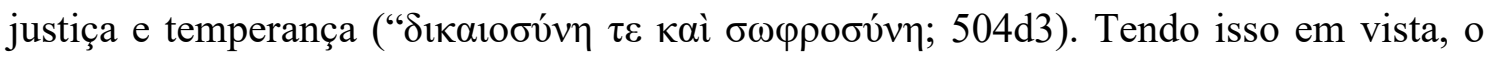
rétor "técnico e bom" presenteará suas plateias, "caso houver algo a ser presenteado, e lhes furtará, caso houver algo a ser furtado". Fará isso "a fim de que a justiça surja na alma de seus concidadãos e da injustiça se libertem, a fim de que a temperança surja e da intemperança se libertem, a fim de que toda e qualquer virtude surja e o vício se parta" (504d5-e4).

De acordo com o argumento, se o ensino da retórica requer o ensino de justiça, como Górgias afirma no começo do diálogo, a função de seus praticantes deveria ser arrancar a injustiça (519d3) de seus ouvintes e aprendizes, ou seja, interromper uma vida vivida de acordo com vícios e desarmonia da alma, voltada aos prazeres insaciáveis. Para 
Journal of Ancient Philosophy ISSN 1981-9471 - FFLCH/USP www.revistas.usp.br/filosofiaantiga
J. anc. philos. (Engl. ed.), São Paulo, v.13, n.2. p. 65-95, 2019.

DOI: http://dx.doi.org/10.11606/issn.1981-9471.v13i2p65-95

Sócrates, parece claro que não é isso que a retórica praticada e defendida por seus interlocutores- o que não é suficiente para descartar a possibilidade de um tipo de retórica capaz de fazê-lo.

A boa retórica tem em sua disposição uma associação com o bem e não com o prazer, pois a este último "não concede graça, mas o combate ( $\delta 1 \alpha \mu \alpha \chi o ́ \mu \varepsilon v o v)$ " (513d45). Essa é, conforme torna-se claro na ocasião da autoproclamação de Sócrates como um dos únicos verdadeiros homens políticos, uma referência à sua própria prática - já que, ao mesmo tempo que afirma ter sido constrangido por Cálicles a agir "como um verdadeiro orador público ( $\dot{\alpha} \lambda \eta \theta \tilde{\omega} \varsigma \delta \eta \mu \eta \gamma o \rho \varepsilon \tilde{\imath} v)$ " (519d5), não profere os discursos que profere "de tempos em tempos visando o deleite", mas "o supremo bem e não o que é

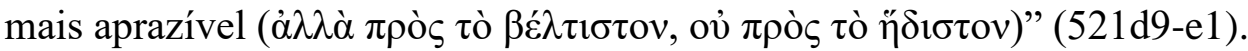

Os argumentos positivos para a defesa da boa retórica e da filosofia, no entanto, são mais obscuros do que as críticas à retórica ateniense. Sócrates não descreve detalhadamente o modo como a filosofia efetuaria o bem na alma dos indivíduos, como seria possível ensinar o que é justo a quem não sabe, ou mesmo se boa retórica e filosofia são idênticas. Sabemos que o bem é o seu critério último, mas a exposição de Sócrates parece ser limitada pela incompatibilidade flagrante entre o seu tipo de método e o discurso com o qual seus adversários estão acostumados. Talvez por isso, a maioria dos estudos a respeito do Górgias não se detêm a respeito da possibilidade aventada por Sócrates, mais propositiva, de uma contrapartida à prática dos sofistas.

A hipótese que eu defendo é de que, no Górgias, Platão está fazendo uma exibição dramática do modo como a boa retórica poderia ser posta em prática. Se a retórica defendida por Cálicles é classificada como ко $\lambda \alpha \kappa \varepsilon i ́ \alpha$, cuja capacidade é a produção de prazer - intrínseco e extrínseco, ou próprio e alheio, às almas justas ou injustas -, à filosofia (fazendo uso da "boa retórica") caberia, em consonância com as demais dicotomias estabelecidas no diálogo, a potência da produção de dor ${ }^{43}$ nas almas injustas, mas tendo como fim o bem - próprio e alheio. ${ }^{44}$ Assim, a partir da crítica ao hedonismo

\footnotetext{
${ }^{43}$ A oposição entre prazer e dor é explicitada, por exemplo, em 475a.

${ }^{44} \mathrm{Cf}$. 504d-e: "Portanto, aquele rétor, técnico e bom, terá isso em vista quando volver às almas os discursos que vier a proferir e todas as suas ações, e lhes presenteará, caso houver algo a ser presenteado, e lhes furtará, caso houver algo a ser furtado. Ele terá sua mente continuamente fixa nesse escopo, a fim de que a justiça surja nas almas de seus concidadãos e da injustiça se libertem, a fim de que a temperança surja e da intemperança se libertem, a fim de que toda e qualquer virtude surja e o vício parta." (504d-e) A diferença entre a retórica e a filosofia, poderíamos dizer,
} 
Journal of Ancient Philosophy ISSN 1981-9471 - FFLCH/USP www.revistas.usp.br/filosofiaantiga
J. anc. philos. (Engl. ed.), São Paulo, v.13, n.2. p. 65-95, 2019.

DOI: http://dx.doi.org/10.11606/issn.1981-9471.v13i2p65-95

e da defesa da justa punição no mito final do diálogo, operar-se-ia a última inversão dicotômica socrática, uma inversão sensorial entre dor e prazer.

Sócrates faz algumas alusões à potência da punição e sua relação com o bem ao longo do diálogo; a conclusão de sua discussão com Polo, por exemplo, é de que o melhor que poderia acometer a alma de alguém que praticou injustiças seria a punição: porque "pagar a pena" devida por alguém que "cometeu injustiça" é a "libertação ( $\alpha \dot{\pi} \alpha \lambda \lambda \alpha \gamma \eta$ ) deste mal”, enquanto "não pagar a justa pena, quando cometida a injustiça, é naturalmente o primeiro e o maior de todos os males" (479d). Dado que qualquer punição é necessariamente o exercício de uma ação cujo efeito é gerar dor, o argumento ganha mais importância à luz da crítica ao hedonismo no final do diálogo. Em 499e, Sócrates retoma a conclusão de sua discussão com Polo, e afirma uma tese a respeito das sensações: assim

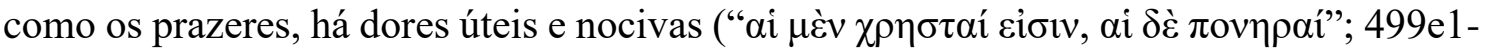
2).

As implicações dessa ideia, no entanto, só serão completamente ilustradas na narrativa evocada por Sócrates no fechamento da conversa, em que a inversão de valores proposta desde o início é finalmente radicalizada. Respondendo ao prenúncio dramático de Cálicles sobre a sua condenação à morte - no qual proclama que, caso o filósofo fosse levado a tribunal, ele certamente sofreria a pena máxima -, Sócrates evoca versos de Eurípides que propõem uma possível inversão entre vida e morte. Essa inversão será levada a cabo no mito, quando a alusão ao julgamento em vida de Sócrates é substituída pelo tribunal do pós-vida (523a3-525a7).

Sob o reinado de Crono, havia a lei segundo a qual as almas dos homens, após a morte, seriam divididas entre a Ilha dos Venturosos ("e lá habitariam em absoluta felicidade e apartado dos males") e o Tártaro ("o cárcere do desagravo e da justiça") de acordo com as suas ações em vida: o homem "cujo curso de vida foi justo e pio" seria enviado para o primeiro, enquanto o "homem de uma vida injusta e ímpia", ao segundo destino. No entanto, o processo era viciado, uma vez que os juízes, ainda vivos, julgavam os homens no último dia de suas vidas, antes de morrerem. Quando Pluto e os demais

também se dá em vistas do tipo de fim ao qual cada uma delas exerce sua potência. Enquanto o fim da má retórica está no prazer, ou seja, na dimensão dos apetites, a filosofia visa o bem verdadeiro. Nesse sentido, a potência de produção de dor se realiza apenas em um sentido intrínseco, quando em contato com almas injustas, mas não no sentido extrínseco, pois a produção de dor não é o fim último da filosofia. 
Journal of Ancient Philosophy ISSN 1981-9471 - FFLCH/USP www.revistas.usp.br/filosofiaantiga
J. anc. philos. (Engl. ed.), São Paulo, v.13, n.2. p. 65-95, 2019.

DOI: http://dx.doi.org/10.11606/issn.1981-9471.v13i2p65-95

responsáveis pela Ilha dos Venturosos se dirigem a Zeus e apontam as falhas de julgamento, devido às quais os homens estavam sendo enviados para os lugares errados, o deus decide alterar o processo. Zeus afirma que "é preciso julgá-los desnudados" de seus corpos, progênies e riquezas, assim como livres das inúmeras testemunhas que os acompanhavam em vida, de modo a tornar o julgamento justo.

Sócrates apresenta uma interpretação do poema: o motivo pelo qual Zeus postula o julgamento para o pós-vida é a separação entre alma e corpo, que permite que a alma seja ao mesmo tempo "desnudada do corpo" (525d4) mas ainda preserve as principais características que cultivou em vida, de forma análoga à outra parte. Evocando as imagens da culinária e da ginástica, Sócrates exemplifica: "se o corpo de alguém em vida fosse grande por natureza, ou por nutrição, ou por ambas as coisas, quando morresse, seria um cadáver grande, e se fosse gordo, seria gordo também quando morresse" (524c1-5). O mesmo sucederia à alma: "quando desnudada do corpo, todas essas coisas estão

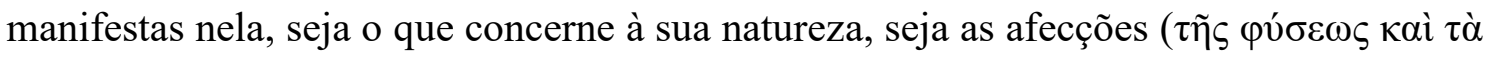
$\pi \alpha \theta \eta ́ f \alpha \tau \alpha)$ que o homem possui na alma mediante cada atividade" (524d4-7).

A alma de cada um é então contemplada pelos juízes mortos e divinos, e julgada de acordo com as marcas nela manifestas. Assim, aquelas que possuem registros das injustiças praticadas em vida são encaminhadas ao Tártaro. É o caso em que o juiz

apoderou-se do Grande Rei, ou de qualquer outro rei ou dinasta, e observou que nada em sua alma era saudável, mas que ela foi açoitada e estava plena de cicatrizes pelos perjuros e pela injustiça, cujas marcas foram impressas na alma por cada uma de suas ações. Ele observou que a mentira e jactância deixaram tudo contorcido e que nenhuma retidão havia porque fora criada apartada da verdade; e viu que, pelo poder ilimitado, pela luxúria, pela desmedida e pela incontinência de suas

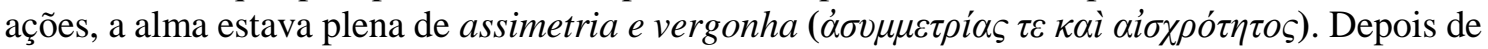
ter visto tais coisas, ele a enviou desonrada direto à prisão, aonde se dirigiu pronta para suportar os sofrimentos que lhe cabiam. (524e5-525a7; itálico meu)

A assimetria - em oposição à desejável ordenação - e a vergonha são localizadas na alma contorcida como resultado de poder ilimitado, luxúria, desmedida e incontinência. Ou seja: trata-se do caso em que os prazeres ocupam um papel principal nas motivações da alma, de forma a corrompê-la e torná-la vergonhosa. Sócrates parece insinuar que esse seria o caso de Cálicles e dos demais defensores da prática política da "má" retórica caso dispusessem de poder ilimitado. Tal corrupção ocorre por um distanciamento da alma em relação à verdade, na medida em que apenas valorizou-se em vida o critério enganoso dos prazeres. 
Journal of Ancient Philosophy ISSN 1981-9471 - FFLCH/USP www.revistas.usp.br/filosofiaantiga
J. anc. philos. (Engl. ed.), São Paulo, v.13, n.2. p. 65-95, 2019.

DOI: http://dx.doi.org/10.11606/issn.1981-9471.v13i2p65-95

A função corretiva da punição fundamenta-se na oposição que a dor é capaz de efetuar ao prazer. Remetendo-se novamente à analogia entre corpo e alma, Sócrates parece conceber uma punição capaz de interromper a insaciabilidade dos prazeres e o seu estímulo à incontinência. Tal qual seria inútil oferecer ao corpo doente e mísero comidas e bebidas aprazíveis e satisfação de apetites, à alma "sucederia o mesmo": "Enquanto for viciosa por ser estulta, intemperante, injusta e ímpia, ela deverá resistir aos apetites e não se permitir fazer senão aquilo que a torne melhor", pois isso "é o melhor para a própria alma" (505a-b).

Mas que tipo de punição Sócrates tem em mente?

\section{A Vergonha como Punição e Paradigma}

A punição da boa retórica deve ser capaz de produzir dor na alma de quem sofre como pena pelos atos injustos, mas ter um potencial corretivo. Essa punição deve ser compatível com uma dimensão pública, de modo a fazer quem a sofre servir de exemplo para outros. E deve poder manifestar os aspectos tortos e vergonhosos da alma de uma pessoa, após ela ter sido desnudada; se nem sempre é capaz de melhorar a alma do próprio indivíduo, no mínimo a faz de modelo para as demais.

À resistência de Cálicles de concordar e continuar na discussão na parte final do diálogo, Sócrates afirma: "Esse homem não tolera ser beneficiado e sofrer aquilo sobre o que discutimos: ser punido" (505c3). A minha tese é de que Sócrates está propondo, então, um tipo de punição corretiva que é realizada através do ع̌ $\lambda \varepsilon \gamma \chi 0 \varsigma$ filosófico. Assim como a adulação é o meio através do qual a retórica é capaz de produzir prazer, a vergonha pode ser a emoção pela qual a filosofia (a "boa retórica") é capaz de exercer sua potência de produção de bem e correção, infligindo dor em seus ouvintes/interlocutores, mas impelindo-os à decisão correta. ${ }^{45}$

Haveria, portanto, uma justificativa filosófica - se quisermos, doutrinal - para o modo como a discussão se desenrola no Górgias, com Sócrates refutando os seus

45 Como afirma Radcliff G. Edmonds III em sua interpretação do mito, "a imagem da alma açoitada e marcada do Grande Rei, despida de qualquer cobertura ou amparo e examinada pelo conhecedor de justiça, ilustra o modo através do qual Sócrates testa seus interlocutores" (2012, p. 166). Em outras palavras, "as punições do pós-vida prescrita para os malfeitores retrata o sofrimento que a vergonha do č $\lambda \varepsilon \gamma \chi 0 \varsigma$ inflige" (idem). 
Journal of Ancient Philosophy ISSN 1981-9471 - FFLCH/USP www.revistas.usp.br/filosofiaantiga
J. anc. philos. (Engl. ed.), São Paulo, v.13, n.2. p. 65-95, 2019.

DOI: http://dx.doi.org/10.11606/issn.1981-9471.v13i2p65-95

interlocutores através da vergonha. Provado que os defensores e praticantes da retórica cometem atos injustos, uma vez que praticam uma falsa $\tau \dot{\varepsilon} \chi v \eta$ sem nenhum compromisso com o ensino da justiça e estimulando os prazeres e vícios nas almas dos espectadores, resta também a eles pagar a devida pena - o que seria, inclusive, benéfico para a sua alma.

O modelo das refutações no Górgias, aliás, seria o único método possível para lidar com esse tipo de interlocutores. ${ }^{46}$ Esse seria o propósito da presença no diálogo de personagens como Górgias, Polo e Cálicles. A vergonha seria capaz de atingir em um registro não apenas racional - através da contraposição resultante da produção de dor uma alma distorcida que, corrompida pelo exercício constante dos apetites, apenas responde a estímulos sensoriais como o prazer.

A produção de dor resultante da vergonha, assim, cumpre uma função também para o combate contra o hedonismo que Sócrates está travando no Górgias. ${ }^{47}$ Ela é capaz de abalar interlocutores cujos valores não se pautam no conhecimento resultante de uma coerência temperante, mas no senso comum e em intuições, que fomentam e são fomentados por uma prática que se funda no prazer e cuja relação com a justiça é simulada. Em outras palavras, a única possibilidade de que estes personagens se convençam é através de motivações mais próximas a estímulos sensoriais do que a argumentos racionais. Através da produção da dor resultante da vergonha, mais do que demonstrar os seus argumentos em um encadeamento lógico, Sócrates estaria mostrando que existe algo de insustentável existencialmente na posição de seus oponentes.

${ }^{46}$ Conforme já apontou Jessica Moss (2005). Segundo Moss, o objetivo de Platão no Górgias seria mostrar como "o apelo aos sentimentos de vergonha e admiração em uma pessoa podem conseguir, quando os argumentos racionais não são suficientes, levá-la a ver que um prazer prejudicial deve ser evitado, ou que uma dor benéfica deve ser perseguida" (Moss, 2005, p. 140). Contudo, diferentemente de Moss - que evoca a tripartição da alma da República e a relação ali

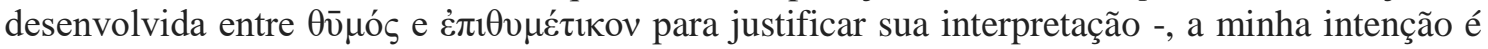
mostrar que o Górgias já contém os elementos necessários, muitos deles expostos dramaticamente, para que façamos uma interpretação a respeito da função atribuída por Platão à vergonha.

${ }^{47}$ Segundo Moss (op.cit., p. 148), há dois motivos para que a vergonha supere a atração pelo prazer: "Primeiro, como muitos já reconheceram, a vergonha é uma emoção auto-referente:

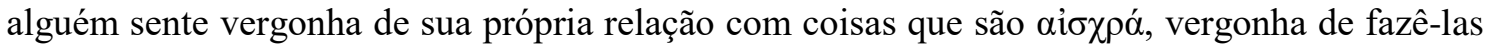

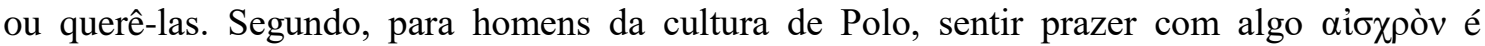
particularmente vergonhoso - mais do que fazer algo aioxpòv por razões alheias; isso é um fato que Platão vai levantar quando Sócrates envergonha Cálicles. Esses dois fatos nos dão razoes para pensar que quando a vergonha e o prazer entram em conflito, a vergonha pode vencer." (trad. livre) 
Journal of Ancient Philosophy ISSN 1981-9471 - FFLCH/USP www.revistas.usp.br/filosofiaantiga
J. anc. philos. (Engl. ed.), São Paulo, v.13, n.2. p. 65-95, 2019.

DOI: http://dx.doi.org/10.11606/issn.1981-9471.v13i2p65-95

Assim, dois dos objetivos centrais para Sócrates no Górgias estariam articulados. Ao relacionar a retórica ao hedonismo, e a filosofia à vergonha, Platão está nos falando não só de como os prazeres e as emoções se relacionam na teoria, mas apontando a filosofia como uma espécie de método de antídoto contra as atrações da vida voltada aos prazeres. Não se trata somente de uma divisão teórica de campos de conhecimento. A vergonha é capaz de operar como antídoto e interferir na "parte da alma" em que os apetites são cultivados, e, através de algo como um tratamento de choque, Sócrates espera fazer com que seus adversários revejam seus valores.

O mito final lança luz sobre as afirmações anteriores de Sócrates a respeito da boa retórica e de sua função na cidade, levando a outro nível a delimitação entre a retórica e a filosofia. Platão, consciente do julgamento de Sócrates, usa o mito como artifício dramático para mostrar a injustiça que fundamentaria a condenação do seu mestre, e postula metafisicamente a possibilidade de um processo cujos critérios fossem mais justos, livres do registro das aparências.

A vergonha e a produção de um certo tipo de dor exercem um papel não de finalidade ${ }^{48}$, mas de meio através do qual é possível estimular a alma a "resistir aos apetites e não se permitir fazer senão aquilo que a torne melhor" (505b3-4). Sócrates "seria tomado pela vergonha", não caso fosse condenado injustamente em um tribunal, sofrendo uma injustiça, mas se não fosse capaz de "prover um socorro" (522d4) a si mesmo, a saber, "do mal supremo" da "injustiça" (509b), após ter provado que é pior e mais vergonhoso cometer injustiça a sofrê-la. ${ }^{49}$ Este argumento é mais central do que parece à primeira vista, sob a luz do julgamento de Sócrates: ele está mais uma vez definindo a vergonha como um sentimento punitivo resultante de ações injustas, uma pena a ser paga não só por seus interlocutores do Górgias, mas por seus condenadores do tribunal.

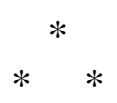

\footnotetext{
${ }^{48}$ V. novamente 499e3-4: "Então, o mesmo não sucede às dores: umas são úteis e outras nocivas?"; "Não se deve, então, escolher e usar os prazeres e as dores úteis?"

${ }^{49}$ Em oposição à acusação que faz àqueles que o processaram, já na primeira página da Apologia,

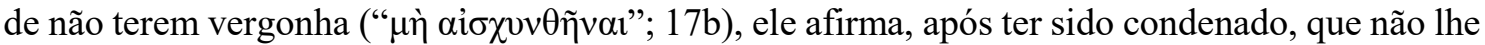
faltam palavras, mas um senso de falta de vergonha para que se submetesse às humilhações de ter que agradar seus ouvintes para que fosse absolvido (38e).
} 
Journal of Ancient Philosophy ISSN 1981-9471 - FFLCH/USP www.revistas.usp.br/filosofiaantiga
J. anc. philos. (Engl. ed.), São Paulo, v.13, n.2. p. 65-95, 2019.

DOI: http://dx.doi.org/10.11606/issn.1981-9471.v13i2p65-95

Análoga às funções que a lisonja e o prazer exercem para a retórica seriam os papeis da vergonha e da punição para a filosofia - uma dicotomia subjacente a todas as outras que Sócrates não pode afirmar diretamente para seus interlocutores, mas que Platão pode exibir dramaticamente. Assim, o papel da vergonha só se revelaria através da leitura do diálogo, à medida que o leitor acompanha o processo psicológico pelos quais passam os interlocutores de Sócrates. Imprescindível para uma análise completa do Górgias seria, portanto, a consideração desses elementos, que fogem à dimensão puramente argumentativa, passível de formalização lógica, das discussões do texto.

Como vimos no caso de Cálicles, o દ̌̉ $\varepsilon \gamma \chi 0 \varsigma$ encontra alguns limites: o jogo de perguntas e respostas através do qual suas posições são refutadas racionalmente, através de argumentos, não passa, para ele, de "sofismas" (497a6). ${ }^{50}$ Os únicos procedimentos capazes de abalar suas convicções são as imagens ridículas, pelas quais Sócrates pretende inverter a tentativa empreendida por seu opositor de ridicularizar a filosofia, jogando em seus próprios padrões. Ainda assim, Cálicles não parece ser convencido até o final do diálogo. Talvez Platão queira justamente nos mostrar os limites da argumentação, na expectativa de que Cálicles possa servir de algo como um paradigma negativo para o tipo de vida que defende.

Basta lembrarmos que Platão prevê "duas" funções para a punição das almas injustas no mito do julgamento em pós-vida: a primeira, corretiva, é capaz de fazer a alma de quem sofre ser afastada da tentação dos prazeres. No entanto, algumas almas, certamente as demasiadamente assimétricas e vergonhosas, são incuráveis.

Mas os que são beneficiados e que recebem a justa pena infligida por deuses e homens são aqueles que cometeram erros curáveis; contudo, é por meio de sofrimentos e dores que eles são beneficiados, aqui como no Hades, pois não há outro modo de se livrarem da injustiça. Por outro lado, os que cometeram as injustiças mais extremas e tornaram-se incuráveis devido a esses atos injustos, tornam-se modelo ( $\pi \alpha \rho \alpha \delta \varepsilon i ́ \gamma \mu \alpha \tau)$, embora eles próprios jamais possam obter alguma vantagem porque são incuráveis. Não obstante, são os outros que obtêm alguma vantagem disso, aqueles que os veem experimentar, ininterruptamente, os maiores, os mais dolorosos e os mais temíveis sofrimentos por causa de seus erros, dependurados no cárcere de Hades como simples

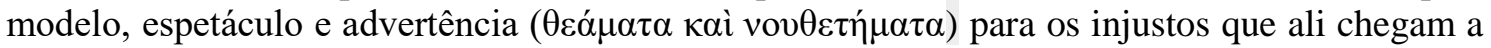
todo instante. (525b5-c8)

${ }^{50}$ V.n. 42. 
Journal of Ancient Philosophy ISSN 1981-9471 - FFLCH/USP www.revistas.usp.br/filosofiaantiga
J. anc. philos. (Engl. ed.), São Paulo, v.13, n.2. p. 65-95, 2019.

DOI: http://dx.doi.org/10.11606/issn.1981-9471.v13i2p65-95

As almas incuráveis, talvez por estarem de tal modo absortas num ciclo de satisfação de apetites, tornam-se completamente viciadas e, assim, incapazes de contemplar qualquer outro tipo de bem; por isso, não podem mais ser corrigidas. Neste caso, a punição tem apenas uma função demonstrativa, pois sua potência de contraposição ao vício não mais funciona.

A alma de Cálicles é incurável: sua incapacidade de deixar-se ser tratado pela filosofia, cuja consequência é o completo colapso de sua discussão com Sócrates, se dá porque ele não admite sofrer a devida punição. O prognóstico de Sócrates é de que ele "será incapaz de socorrer a si mesmo" (526e5) no julgamento pós-vida. "Quando te apresentares ao juiz, o filho de Egina, e ele te levar preso, ficarás turvado e boquiaberto neste lugar tanto quanto eu ficarei aqui, e talvez alguém rache também a tua têmpora de forma desonrosa e te ultraje de todos os modos" (526e5-a4). A última inversão, entre a legitimidade do julgamento em vida e em morte, resulta também na inversão entre a condenação mais justa e legítima, daquele que sofre punição pelos atos que cometeu. A incomensurabilidade entre Cálicles e Sócrates é gerada pela falta de $\sigma \omega \varphi \rho \sigma v \dot{v}$ e a consequente incapacidade de atender ao $\lambda o ́ \gamma o \varsigma$ do primeiro, condições taxadas de vergonhosas pelo segundo:

Pois é vergonhoso encontrarmo-nos nessa condição que patentemente nos encontramos, e incorrermos nessa insolência juvenil como se fôssemos algo, a quem jamais as coisas parecem ser as mesmas a respeito dos mesmos assuntos, inclusive a respeito dos mais preciosos (527d5e1).

Assim, ao atentar para a função demonstrativa da alma incurável como paradigma do mito, Platão refere-se também à função exemplar do próprio diálogo: se Polo e Górgias parecem de alguma forma influenciados pela derrota de Cálicles, instigados e clamando pela continuidade da discussão no terceiro ato, talvez a audiência última da ridicularização de Cálicles seja o próprio leitor.

Ao mencionar uma "boa retórica", Platão pode estar se referindo a uma estratégia não totalmente racional da filosofia, que funciona através de imagens - seja a metáfora dos jarros furados, sejam as analogias com as atividades corporais, o mito do julgamento pós-vida, ou mesmo a evocação a elementos do imaginário popular, como representações textuais de tragédias e imagens de estilos de vida repulsivos. Através dos elementos que geralmente categorizamos como literários e dramáticos, o escritor é capaz de convencer 
Journal of Ancient Philosophy ISSN 1981-9471 - FFLCH/USP www.revistas.usp.br/filosofiaantiga
J. anc. philos. (Engl. ed.), São Paulo, v.13, n.2. p. 65-95, 2019.

DOI: http://dx.doi.org/10.11606/issn.1981-9471.v13i2p65-95

sua audiência - seus leitores -, mobilizando casos paradigmáticos, a não mais procurar uma vida intemperante. O leitor implícito do diálogo Górgias, a audiência em que a "boa retórica" teria efeito - poderíamos supor, tal qual a audiência prevista para um exemplo paradigmático de alma incurável no Tártaro - deixa-se afetar por exibições que evocam elementos não puramente racionais, pois já estão em alguma medida inseridas na lógica da incontinência.

Por isso faz muito mais sentido mostrar a vergonha do que defendê-la em um discurso teórico: porque as almas assimétricas, vergonhosas mas curáveis, precisam de estímulos que, ligados à experiência sensorial, contraponham-se aos efeitos do prazer. Assim, o apelo ao exemplo do kívaıঠos, ou a evocação de textos poéticos tradicionais, exerce algum efeito em Cálicles - ainda que limitado, pois sua alma é incurável -, e nos leitores do diálogo, que, frente aos elementos textuais dramáticos, sentem-se ridicularizados em sua possível identificação com qualquer das teses calicleanas.

\section{Conclusão}

A nossa tese demanda elementos geralmente considerados como desenvolvimentos da psicologia moral platônica presentes nos diálogos da chamada "segunda fase", a saber, a divisão da alma em várias partes, que teriam as motivações de caráter específico. Ou seja, a vergonha apelaria às motivações de uma parte da alma, que, em uma determinada harmonia, seria capaz de frear outras motivações - atribuídas, na República, a outra parte, a apetitiva -, que almejam a satisfação dos apetites.

É forçoso dizer que as ideias expressas por Sócrates no Górgias, de acordo com a nossa leitura, se afastam da posição tradicional à qual refere-se usualmente como intelectualismo socrático - ou pelo menos a um dos elementos fundamentais do intelectualismo socrático, a saber, a exclusão do papel dos elementos ditos "não puramente cognitivos" para a tomada de decisões. Talvez seja possível afirmar, inclusive, que a importância das emoções e dos prazeres é o tema central do diálogo, dado o próprio direcionamento temático que Sócrates dá à discussão, enfatizando a vergonha. Essa importância dos elementos "não-cognitivos" percorre as discussões de todo o texto e parecem corroborar a visão de que no Górgias, o Sócrates de Platão não defende uma visão estritamente intelectualista das motivações morais - ou, ao menos, que sua 
Journal of Ancient Philosophy ISSN 1981-9471 - FFLCH/USP www.revistas.usp.br/filosofiaantiga
J. anc. philos. (Engl. ed.), São Paulo, v.13, n.2. p. 65-95, 2019.

DOI: http://dx.doi.org/10.11606/issn.1981-9471.v13i2p65-95

concepção intelectualista não exclui a influência de outros elementos, não-racionais, como a vergonha. ${ }^{51}$

No entanto, aqui ainda não podemos localizar uma teoria das partes da alma completamente definida. Sócrates faz menções en passant a diferentes partes da alma no Górgias - 493a, 493b - curiosamente retomando, ao final do diálogo (509e), uma tese aparentemente intelectualista, ao dizer expressamente que "todos os que cometem injustiça a cometem involuntariamente". O máximo que se pode afirmar é que Platão passa a considerar, no Górgias, a potência das emoções a partir da atração das dores e prazeres - o que, em uma conjectura, poderíamos dizer que o leva a desenvolver a teoria tripartite da República.

Por isso, no que diz respeito à teoria platônica das emoções e das motivações, o Górgias é um diálogo um tanto singular. Há certo consenso sobre seu lugar na cronologia de composição dos diálogos, um período de transição entre a primeira e a segunda fases da obra de nosso autor. Em termos teóricos, isso poderia significar que Platão começa aqui a testar algumas ideias. Um exemplo é a menção à necessidade da "harmonia da alma", que supõe uma complexificação do conceito de alma a desembocar em uma divisão em diferentes partes a serem harmonizadas. Embora Sócrates ainda não formule tal divisão esquematicamente, é óbvio que, no Górgias, Platão já está preocupado com o papel que as emoções e os prazeres cumprem na economia da "alma desarmoniosa"

Essas preocupações, se não necessariamente desenvolvidas por Sócrates com toda a articulação que o personagem exibe nos diálogos de segunda fase, expressam-se em larga medida no estilo do diálogo. Ao montar uma cena em que Sócrates debate com interlocutores altamente suscetíveis a emoções e prazeres, Platão está tratando esses problemas filosófica e literariamente. Ao denunciar, não só pelas palavras de Sócrates,

\footnotetext{
${ }^{51}$ Brickhouse e Smith, ao proporem uma alternativa à "visão tradicional" de um intelectualismo socrático presente nos primeiros diálogos, afirmam que para Sócrates "o apelo dos apetites e das paixões pode influenciar como julgamos o que está em nosso melhor interesse em um determinado momento (Brickhouse \& Smith, 2010, p. 129)". Assim, a distorção dos prazeres e dores poderia exercer um potencial benéfico ou maléfico, de acordo com a intenção do agente, ainda que não necessariamente se aproximem da verdade. Isso porque "nossos apetites funcionam de tal maneira que eles nos representam seus objetivos como benefícios que temos que perseguir" (Brickhouse \& Smith, 2010, p. 120). A dimensão enganadora do prazer funcionaria de tal forma que "quanto mais nos permitimos a experiência de prazeres de gratificação como os do apetite, menos somos capazes de considerar as razões para resistir a tentação de tais prazeres no futuro". Por isso, "o nosso apetite por tais prazeres torna-se mais desobediente e indisciplinado" (Brickhouse \& Smith, 2010, p. 121).
} 
Journal of Ancient Philosophy ISSN 1981-9471 - FFLCH/USP www.revistas.usp.br/filosofiaantiga
J. anc. philos. (Engl. ed.), São Paulo, v.13, n.2. p. 65-95, 2019.

DOI: http://dx.doi.org/10.11606/issn.1981-9471.v13i2p65-95

mas também pelas reações e atitudes de seus interlocutores, a atração exercida pelo prazer naqueles engajados em uma prática tão bem considerada na sociedade ateniense, Platão, a um só tempo, fundamenta a sua recorrente crítica à retórica e aos sofistas, e mostra uma preocupação com a potência da influência das emoções, prazeres e apetites na opinião e na agência de indivíduos "não-filósofos". Em contrapartida, ao representar Sócrates devolvendo na mesma moeda, utilizando recursos como a vergonha e a ironia para afetar seus interlocutores, Platão alude à possibilidade de que as emoções possam, se bem aplicadas, funcionar a favor de ideias filosóficas.

Platão menciona a "boa retórica" no final do diálogo de modo elíptico para fazer referência à própria obra. Sócrates é evidentemente um filósofo; mas um filósofo que, ao evocar mitos, envergonhar seus interlocutores, fazer longos discursos, admitir estar se comportando como um "verdadeiro orador público", parece propor a possibilidade do uso da retórica, ou de recursos "extra-argumentativos" de forma a exortar um certo tipo de ouvinte ou interlocutor à filosofia. Entre as principais características dessa "boa retórica", há um compromisso com a apologia da virtude e dos valores fundamentados filosoficamente por Sócrates, além da oposição em relação à adulação e a produção de prazer como fim em si mesmo. Deste modo, Platão diferencia filosofia e retórica não apenas em relação ao método e ao tipo de discurso adotado por cada uma das práticas, mas também pelos fins visados por cada uma. A exibição última de como a boa retórica funciona através da vergonha se dá através do próprio diálogo.

Luiz Eduardo Freitas Universidade de São Paulo

\section{Referências Bibliográficas}

Beversluis, J. (2000). Cross-examining Socrates: a defense of the interlocutors in Plato's early dialogues. Cambridge University Press.

Burnet, J. (1968). Platonis Opera, Tomus III, Oxford University Press.

Brickhouse T. C.; Smith, N. D. (2010). Socratic Moral Psychology. Cambridge: Cambridge University Press. 
Journal of Ancient Philosophy ISSN 1981-9471 - FFLCH/USP www.revistas.usp.br/filosofiaantiga
J. anc. philos. (Engl. ed.), São Paulo, v.13, n.2. p. 65-95, 2019.

DOI: http://dx.doi.org/10.11606/issn.1981-9471.v13i2p65-95

Cooper, J. M. (ed.). (1997). Plato - Complete Works. Cambridge: Hackett.

Cooper, J. M. (1999). Reason and Emotion: Essays on Ancient Moral Psychology and Ethical Theory. Princeton: Princeton University Press

Dodds, E. R. (1990). Plato - Gorgias. A Revised Text with Introduction and Commentary. Oxford: Clarendon Press.

Edmonds III, R. G. (2012). "Whip Scars on the Naked Soul: Myth and Elenchos in Plato's Gorgias" In : Collobert, Destrée \& Gonzalez, Brill (org.). Platonic Myths: Studies on the Use and Status of Platonic Myths. Leiden: Brill, p. 165-186.

https://doi.org/10.1163/9789004224360_011

Freitas, L. E. (2018). A imagem do kinaidos no Górgias de Platão. Archai, n. 23, May-Aug., p. 77-107. https://doi.org/10.14195/1984-249x_23_3

Guthrie, W. K. C. (1975). A History of Greek Philosophy. Cambridge, Cambridge University Press (vol.IV).

Irwin, T. H. (1979). Plato. Gorgias. Oxford: Clarendon Press.

Irwin, T. H. (1993) "Say What You Believe." In: Apeiron 26:1-16 - Virtue Love and Form: Essays in Memory of Gregory Vlastos. Vol. 26, eds Terence Irwin and Martha C. Nussbaum. https://doi.org/10.1515/apeiron.1993.26.3-4.1

Kahn, C. H. (1983). Drama and Dialetic in Plato's Gorgias. In; Oxford Studies in Ancient Philosophy (ed. Julia Annas). In: Oxford Tudies in Ancient Philosophy 1, p. 75-121.

Levy, D. (2014). "Socrates vs. Callicles: Examination \& Ridicule in Plato's Gorgias". In: PLATO JOURNAL: The Journal of the International Plato Society 13, 27-36. https://doi.org/10.14195/2183-4105_13_2

Lopes, D. R. N. (2011). Górgias de Platão. Tradução, ensaio introdutório e notas. São Paulo: Perspectiva. Fapesp.

McComiskey, B. (2002). Gorgias and the New Sophistic Rhetoric. Carbondale and Edwardsville: Southern Illinois University Press

McKim, R. (1988). "Shame and Truth in Plato's Gorgias". In: Griswold, C. Platonic Writings / Platonic Readings. New York: Routledge.

Muniz, F. P. (2011). A potência da aparência: um estudo sobre a sensaçãoe o prazer nos Diálogos de Platão. São Paulo: Annablume, 2011.

Moss, J. (2005). Shame, Pleasure and the Divided Soul. Oxford Studies in Ancient Philosophy. Oxford: Carendon.

Nussbaum, M. A fragilidade da bondade: fortuna e ética na tragédia e na filosofia grega. São. Paulo, Martins Fontes, 2009

Nightingale, A. (1995). Genres in Dialogue: Plato and the Construct of Philosophy. New York: Cambridge University Press.

Rudebusch, G. (1992). "Callicles' Hedonism." In : Ancient Philosophy 12.1, p. 53-71. https://doi.org/10.5840/ancientphil199212144

Santas, G. X. (1979). Socrates: Philosophy in Plato's Early Dialogues. London: Routledge \& Kegan Paul.

Vlastos, G. (1995). “Was Polus Refuted?” In: Graham, D. (ed). Studies in Greek Philosophy. Princeton: Princeton University Press, p. 60-64. 